\title{
Cognitive decline following acute viral infections: literature review and projections for post-COVID-19
}

\author{
Rodolfo Furlan Damiano ${ }^{1}$ (i) - Bruno F. Guedes ${ }^{2}$ - Cristiana Castanho de Rocca ${ }^{1}$ Antonio de Pádua Serafim ${ }^{1}$. \\ Luiz Henrique Martins Castro ${ }^{2}$. Carolina Demarchi Munhoz ${ }^{3} \cdot$ Ricardo Nitrini $^{2} \cdot$ Geraldo Busatto Filho $^{1}$. \\ Eurípedes Constantino Miguel ${ }^{1}$. Giancarlo Lucchetti ${ }^{4}$. Orestes Forlenza ${ }^{1}$
}

Received: 6 December 2020 / Accepted: 21 June 2021 / Published online: 25 June 2021

(c) Springer-Verlag GmbH Germany, part of Springer Nature 2021

\begin{abstract}
Recently, much attention has been drawn to the importance of the impact of infectious disease on human cognition. Several theories have been proposed, to explain the cognitive decline following an infection as well as to understand better the pathogenesis of human dementia, especially Alzheimer's disease. This article aims to review the state of the art regarding the knowledge about the impact of acute viral infections on human cognition, laying a foundation to explore the possible cognitive decline followed coronavirus disease 2019 (COVID-19). To reach this goal, we conducted a narrative review systematizing six acute viral infections as well as the current knowledge about COVID-19 and its impact on human cognition. Recent findings suggest probable short- and long-term COVID-19 impacts in cognition, even in asymptomatic individuals, which could be accounted for by direct and indirect pathways to brain dysfunction. Understanding this scenario might help clinicians and health leaders to deal better with a wave of neuropsychiatric issues that may arise following COVID-19 pandemic as well as with other acute viral infections, to alleviate the cognitive sequelae of these infections around the world.
\end{abstract}

Keywords Cognition · Alzheimer's disease $\cdot$ Virus $\cdot$ Dementia $\cdot$ COVID-19 $\cdot$ Prevention

\section{Introduction}

Cognitive impairment is a vital healthcare problem worldwide. Population studies have shown that $3-19 \%$ of the population older than 65 years meet criteria for mild cognitive impairment (MCI) [1,2]. Of these, more than $50 \%$ will develop dementia [2]. Global prevalence of dementia in the population is $1.3 \%$, and $7.3 \%$ in people aged 65 years or more [3], which is similar to those found in Latin American

Rodolfo Furlan Damiano

rodolfo.furlan@hc.fm.usp.br

1 Departamento E Instituto de Psiquiatria, Hospital das Clínicas da Faculdade de Medicina da Universidade de São Paulo, Rua Dr. Ovídio Pires de Campos, 785, Cerqueira César, São Paulo, SP 05403-903, Brazil

2 Department of Neurology, University of São Paulo, São Paulo, Brazil

3 Department of Pharmacology, Institute of Biomedical Sciences, University of São Paulo, São Paulo, Brazil

4 Department of Medicine, Federal University of Juiz de Fora, Juiz de Fora, Brazil population [4]. Many studies have shown a direct influence of viral infections on cognition, especially in the development of MCI and dementia [5-7]. The high prevalence and the overlap of both conditions underscore the importance of a better understanding of the role of viral infections in the pathogenesis of dementia [8,9].

Viral infections significantly impact world's global burden of medical and neurological diseases [8]. In the last decades, the role of viral infections in cognitive impairment following has been widely discussed [5]. Viruses, such as herpes viruses, cytomegalovirus, human immunodeficiency virus (HIV), Varicela zoster virus (VZV), Epstein-Barr virus (EBV), and Hepatitis $C$ virus, have been implicated in Alzheimer's disease pathogenesis [7, 10]. Mechanisms underlying viral pathogenesis in these conditions may include a direct viral effect or indirect mechanisms, such as inflammation, epigenetic changes, and hypercoagulable changes, that may impact on brain structure and function in healthy or in cognitively impaired individuals [6, 11-15]. Previous reviews have also addressed this topic; however, most of them are not specific to acute viral infections [6], 
restricted to few viral infections (e.g. Herpes virus) [7] or letter to editors [5].

In this context, emerging infectious diseases, especially those affecting the population on a pandemic scale, should be monitored for potential neuropsychiatric compromise. This may be the case of coronavirus disease 2019 (COVID19), which currently challenges physicians and health care professionals not only for its high mortality and severity of clinical manifestations, but also for emergence of atypical and unexpected clinical presentations [16], such as cognitive impairment [17]. Some experts worldwide [18], including those from the Alzheimer's Association, have been interested in studying this potential association, reviewing the most updated evidence towards this topic and proposing a cross-cultural prospective study to assess individuals reporting cognitive impairment and other neuropsychiatric complaints [19]. However, there is still a need of further theoretical studies, especially using a multi-specialist approach, to discuss further this matter and guide for future interventional studies.

To address this matter, we conducted a comprehensive literature review with different specialists (neurologists, geriatrists, psychiatrists, neuropsychologists), to address the available studies that investigated the occurrence of cognitive decline following the most prevalent acute viral infections. Moreover, understanding about the pathophysiology of the cognitive impairment following other viral infections will help to better understand the emergence of neuro-cognitive symptoms among COVID-19 survivors. Post-COVID cognitive impairment may represent an important clinical feature of the disease, and may impose an additional and long-lasting burden, especially psychiatric and cognitive issues, particularly among older adults. Recognizing cognitive impairment following COVID-19 may be essential to promote preventive and therapeutic interventions and help clinicians worldwide to identify and treat this condition. This narrative review aims to bridge this gap, presenting the literature about the impact of viral infections on cognition, as well as to develop a theoretical framework on how COVID-19 impacts in the CNS function and may cause cognitive impairment.

\section{Methods}

We conducted a narrative review of literature following international guidelines for writing narrative reviews [20, 21]. First, two authors have searched three databases (PubMed, Scielo and EMBASE) using the following keywords: "Cognition", "Cognitive Impairment", "Cognitive Decline", "Dementia", Alzheimer's Disease", "Virus", "Acute", "Viral Infection", "Infection", and "Infectious Disease", with restriction of title, abstract and keyword. We selected additional disease-specific parameters ("Herpes simplex type 1", "varicella-zoster", "West Nile virus", "Influenzae", "Japanese encephalitis", "aseptic meningitis", "Acute respiratory distress syndrome"), adding the name of the parameter to the Boolean search. Selected articles were also searched for references. We accepted only articles in English, Spanish, Italian, and Portuguese. Selected articles were discussed with all authors and then included in the review.

\section{Pathophysiology and types of the cognitive impairment following viral infections}

First, it is important to give clear definitions about cognitive decline (or cognitive impairment), mild cognitive impairment, dementia and Alzheimer's disease, respectively. Cognitive decline can be understood as the loss of cognitive performance. It can be linear and natural or can have a nonlinear and accelerated characteristic of loss [22]. The latter, when not impact activities of daily life, is called mild cognitive impairment (MCI), whereas dementia notably interferes on daily life [2]. The most common cause of dementia is the Alzheimer's disease, which can be defined as a chronic neurodegenerative disorder, characterized by the accumulation in brain of amyloid- $\beta$ (A $\beta)$ and tau protein [23]. Cognitive impairment may be caused by viral infections associated with direct invasion of the central nervous system [11, 24], or as an indirect effect of systemic infections not typically causing CNS infection (e.g. cytokine storm, neuro-inflammation, hypercoagulability) $[11,24]$.

Moreover, encephalitis is defined as an inflammation of the brain parenchyma associated with neurologic dysfunction, which usually manifests clinically with seizures, encephalopathy, focal neurologic signs and symptoms. In 2013, the International Encephalitis Consortium issued standardized and now widely case definitions for encephalitis. Diagnosing encephalitis requires demonstration of altered mental status decreased or altered level of consciousness, lethargy or personality change) lasting $>24 \mathrm{~h}$, combined with at least two minor criteria (fever, new-onset seizures, focal signs, CSF pleocytosis, parenchymal abnormalities on neuroimaging, or typical electroencephalogram findings) for possible encephalitis, and three minor criteria for probable encephalitis [25]. For aseptic meningitis, Brighton Collaboration case definitions are widely used. Diagnosing aseptic meningitis requires clinical evidence of meningitis (fever, headache, vomiting, nuchal rigidity), and CSF pleocytosis, and negative CSF culture [26]. Distinguishing between meningitis and encephalitis is often elusive, given the shared disease mechanisms and clinical overlap. To avoid such confusion, the more encompassing term "meningoencephalitis" is frequently used interchangeably with meningitis and encephalitis. 
Below, we will summarize the most important findings regarding six viruses that causes acute infections and its impact on cognition.

\section{Herpes simplex virus type 1}

\section{Molecular biology and epidemiology}

Herpes simplex virus type 1 (HSV-1) is a double-stranded DNA virus of the herpesviridae family. It is the leading cause of acute infectious encephalitis worldwide [27-29]. The incidence of HSVE is estimated to be between 2 and 4 cases/1,000,000, without clear regional differences [30, 31].

\section{Mechanisms of infection}

HSV primary infection involves skin or mucosae. Following primary infection, the virus infects sensory neurons and, ultimately, the dorsal root ganglia, via axonal transport. After prolonged latent infection, the virus may access the central nervous system by retrograde transport through trigeminal or olfactory nerves [32]. The predilection for involvement of mesiotemporal and limbic cortices may be explained by the intense connectivity between the olfactory nerves and the limbic system [33].

\section{Clinical manifestation}

Acute herpes simplex encephalitis presents commonly with prodromal symptoms, such as fever and respiratory symptoms, which progress over several days to encephalopathy, focal neurological signs and seizures [32, 34]. Neuroimaging shows characteristic but variable degrees of restricted diffusion, T2/FLAIR hyper-intensities and contrast enhancement in the mesial temporal lobes, orbito-frontal, insular and anterior cingulate cortices, frequently bilateral and asymmetrical $[32,34]$. Typical CSF findings include mild-to-moderate pleocytosis $\left(10-200 \mathrm{WBC} / \mathrm{mm}^{3}\right)$, mildly elevated protein $(50-100 \mathrm{mg} / \mathrm{dL})$ and normal glucose [32].

\section{Impacts on cognition}

Herpesviridae viruses can be implicated in late-onset Alzheimer's disease pathogenesis $[35,36]$, probably due to the increased amyloid- $\beta$ amyloidosis [37]. Early reports from the pre-acyclovir era describe severe anterograde amnesia due to bilateral hippocampal damage in surviving HSV-1 patients [38]. A few patients followed longitudinally over long periods [39-46], display persistent severe anterograde and retrograde amnesia, with relatively preserved remote memories, the hallmark of bilateral hippocampal lesions. The severity of retrograde amnesia in HSV-1 patients is possibly associated with greater involvement of temporal lobe structures, including the temporal poles and temporal neocortical regions [43].

Memory deficit severity correlates with the extent of medial temporal lobe involvement and is the most important late finding in HSV encephalitis [47]. Bilateral lesions are associated with more profound cognitive deficits, involving semantic memory impairment and visual agnosia [42, 48]. Executive dysfunction, possibly due to orbito-frontal and anterior cingulate cortices damage is also recognized in HSV-1 encephalitis [49].

Although HSV-1 survivors may show improved cognition over time, cognitive impairment is an enduring longterm consequence of brain damage. Severe memory impairment is recognized in $40-58 \%$ of patients one year after the encephalitis [50-52], and $80 \%$ of patients display persistent mild cognitive deficits three years after the acute episode [53]. The advent of acyclovir, in the late 1980s, considerably modified the prognosis of HSV-1 encephalitis [54-56]. Mortality rates have dropped below $20 \%[34,57]$. Cognitive impairment, however, remains very common in acyclovirtreated patients [52].

\section{Varicella zoster virus}

\section{Molecular biology and epidemiology}

Varicella zoster virus (VZV) is a ubiquitous exclusively human DNA virus of the herpeviridae family and is the second cause of encephalitis worldwide [27, 29, 58].

\section{Mechanisms of infection}

Following primary infection, the VZV remains latent in cranial, dorsal root, and autonomic ganglia [59]. Iatrogenic immunosuppression and advanced age are associated with decreased cell-mediated immunity, which leads to VZV reactivation and neurological complications [60]. VZV reactivation shares many mechanisms with HSV-1 reactivation, and retrograde axonal transport within sensory neurons plays an important role [61].

\section{Clinical manifestation}

VZV can cause miscellaneous central nervous system diseases, including as meningitis, encephalitis, myelitis and CNS vasculopathy which frequently overlap [60]. Most frequently, VZV reactivates as shingles, and the infection is limited to the peripheral nervous system, with rash resolution over a few weeks. Occasionally, especially in immunocompromised patients, meningoencephalitis occurs. Clinical presentation is similar to other encephalitis syndromes, with varying degrees of encephalopathy, seizures, and headache. CSF studies show the typical profile 
of viral meningoencephalitis, with $50-300 \mathrm{WBC} / \mathrm{mm}^{3}$, and $40-150 \mathrm{mg} / \mathrm{dL}$ of protein [62, 63]. In encephalitis cases, neuroimaging shows encephalitic abnormalities nearly as frequently as signs of intracranial vasculitis [62].

\section{Impacts on cognition}

Studies assessing prognosis using hard endpoints in the postacyclovir era showed neurological impairment in 20-60\% of patients upon hospital discharge [62-64], 55\% after one month, $51 \%$ after three months and $71 \%$ after one year [62, 65] after the acute episode. Recent attention has been drawn to potential long-term effects of herpes virus infection on cognition in the absence of an acute neurological syndrome. Viral presence in the CNS may interfere with pathogenic mechanisms related to neurodegenerative diseases, such as Alzheimer's disease (AD) [7, 10]. According to the 'viral hypothesis of AD', this interaction may be non-specifically associated with up-regulation of inflammatory responses and oxidative stress, which are secondary, but relevant components of the amyloid cascade. This interaction may also operate through a specific mechanism within the core pathogenesis, hastening amyloid overproduction $[10,12]$.

\section{Japanese encephalitis}

\section{Molecular biology and epidemiology}

Japanese encephalitis (JE) is the most common cause of encephalitis in Asia, affecting mainly children. Adult cases are increasingly reported [66]. JE is also a relevant cause of encephalitis in the western pacific, and JE cases have also been reported in Australia [67]. The disease is caused by the Japanese Encephalitis virus (JEV), a mosquito-borne singlestranded RNA virus of the flaviviridae family. The disease is usually transmitted to humans following the pig-mosquito-human route [68].

\section{Mechanisms of infection}

Following subcutaneous inoculation, the JE virus infects various parts of the brain, suggesting a hematological route of infection, which could be explained by infection of endothelial cells and subsequent transcellular transport into the brain parenchyma, and paracellular leakage through damaged blood-brain barrier or blood-CSF barrier [69].

\section{Clinical manifestation}

Only one in 25 to one in 1000 infections are symptomatic [70]. Patients typically present with fever and encephalopathy, often associated with seizures and moderate CSF pleocytosis. Neuroimaging may reveal specific abnormalities in the thalami in $22 \%$ of cases [71].

\section{Impacts on cognition}

Around $45-64 \%$ of survivors show neurological sequelae on hospital discharge [72-74]. In a Chinese retrospective series of 50 JE patients [66], 12\% died during hospital admission, $75 \%$ had significant functional limitations upon discharge, and $39 \%$ of survivors had major limitations after 18 months.

These findings are in agreement with an early study conducted in Japan that found that $29 \%$ of patients had "detectable neurological sequelae" one year after the encephalitis episode [75], as well as with recent studies conducted in India and Japan, showing that $100 \%$ of patients had neurologic deficits on hospital discharge [76], 44\% of patients had at least one neurological CNS sequel one to two years post encephalitis [74]. Cognitive deficits, especially intellectual disability and memory loss have been presented both in children and adults $[72,74]$ as well as memory learning in rats [77].

\section{West Nile virus encephalitis}

\section{Molecular biology and epidemiology}

West Nile virus (WNV) is a single-stranded RNA virus of the flaviridae family. The primary hosts are birds, and humans can be infected through transmission by mosquitoes. WNV is enzootic in Africa, Europe and Asia, and is also endemic in the United States, where over three million infections have occurred between 1999 and 2010 [78]. In endemic regions, WNV accounts for a significant proportion of encephalitis cases [28, 79]. In the United States, WNV was the second leading cause of viral encephalitis in the 2000-2010 period [28]. WNV can also cause massive outbreaks worldwide [80]. In Europe, the incidence of WNV disease rose sevenfold in 2018 (from the previous year), with a total 181 deaths [81]. A severe outbreak was also experienced in Romania, where incidence peaked at 1.5/100,000 in the year of 1996 .

\section{Mechanisms of infection}

Although the exact disease mechanism is unknown, current hypothesis suggests the WNV enters the CNS hematogenously after crossing the blood-brain barrier, by endothelial replication or through transneuronal axonal transport within olfactory or peripheral somatic nerves [82]. 


\section{Clinical manifestations}

Most cases are mild or asymptomatic. Nervous system involvement (meningitis, encephalitis, acute flaccid paralysis) occurs in $1 \%$ of patients. Acutely, WNV encephalitis (WNE) patients usually present with fever and encephalopathy. Movement disorders, including myoclonus and parkinsonism, and motor weakness are common [83]. Mortality rates can be as high as $15-20 \%$, with older adults at a higher risk [84].

\section{Impacts on cognition}

WNE patients experience significant morbidity during the initial months following acute infection. Most cases require rehabilitation $[85,86]$. Movement disorders persist for months to years [83, 87-91]. Eighty percent of WNE patients report persistent WNV-related symptoms one year after infection.

Using comprehensive neuropsychological assessment tools, [88] showed that patients with neuro-invasive WNV disease displayed mild cognitive deficits in immediate and delayed memory, and more significant cortical thinning than controls on magnetic resonance imaging [88]. These findings were supported by another study conducted in Canada [89].

\section{Aseptic meningitis}

\section{Molecular biology and epidemiology}

Although the exact cause is unknown in many cases, viral meningitis is a leading cause of aseptic meningitis (AM) worldwide. Viral meningitis accounts for roughly $40 \%$ of all AM cases [92, 93]. The rates of detection of causative pathogens, particularly viruses, increases as more molecular and immunological testes are used [94], and the diversity of AM-causing viruses is ever-increasing [95], so many physicians consider AM of unknown cause as presumably of viral etiology [96]. Enteroviruses, VZV and herpes simplex virus type 2 are common causative agents.

\section{Mechanisms of infection}

In aseptic meningitis, mechanisms of infection are specific to the underlying infection associated. Herpes simplex and VZV-associated aseptic meningitis are usually associated to reactivation and its associated mechanisms, as described above. Human enteroviruses, a major cause of AM worldwide, are primarily acquired through the fecal-oral or fecal-hand-oral route (and occasionally by aerosolized oral secretions). Following infection in the oropharynx, the virus spreads to the gastrointestinal tract. The following viremia is occasionally followed by entry to the central nervous system through hematogenous spread [97, 98]. Once the virus enters the cerebrospinal fluid, it triggers accumulation of inflammatory cells, release of inflammatory cytokines, such as interleukin (IL)-1B, IL-6 and tumor necrosis factor (TNF)-alpha, which leads to increased permeability of the blood-brain barrier and additional inflammation, leading to typical symptoms of meningeal irritation [97].

\section{Clinical manifestation}

AM encompasses a clinical syndrome including patients with clinical and laboratory signs of meningitis, such as headache and nuchal rigidity, for which a bacterial cause of meningitis is excluded [26]. These symptoms of meningitis frequently follow prodromal systemic symptoms that are specific to the associated infection: shingles in VZVdisease, respiratory symptoms in enterovirus D68, diarrhea and hand-foot-and-mouth syndrome in other human enteroviruses [99]. The hallmark that differentiates AM from encephalitis is absence of altered mental status, which is the major diagnostic criterion for encephalitis, which is usually accompanied by absence of parenchymal abnormalities on neuroimaging and electroencephalogram studies [25].

\section{Impacts on cognition}

Acute AM is usually considered a benign condition not associated with long-term neurological sequelae. The perceived benign course may reflect, in fact, an underestimation of cognitive impairment in acute viral meningitis, due to the paucity of studies assessing quality of life and neuro-cognitive outcomes in this condition, as compared to the widely recognized consequences of acute bacterial meningitis (BM) and acute viral encephalitis (VE) [100].

Longitudinal studies in AM did not report a significant morbidity in the long term $[24,100,101]$. The inclusion of comprehensive tools for mental status and cognition revealed that AM patients might present with subtle visual memory and cognitive processing speed impairment [24], and worse global mental health status, compared to healthy controls. [101, 102].

\section{Influenza viruses}

\section{Molecular biology and epidemiology}

Influenza viruses are single-stranded RNA viruses of the Orthomyxoviridae family. Influenza types B and C infect predomonantly humans and typically do not cause pandemics. Influenza type A viruses may infect other mammals and avians, which leads to mixing genetic material and epidemics in naïve populations. Influenza viruses, including the most common subtypes A (H1N1), A (H3N2), B (Victoria), 
and B (Yamagata) are common causes of acute lower respiratory infections in humans [103], accounting for at least four large-scale pandemics in the last century [104]. An important complication of influenza infection (but not exclusive of it) is the acute respiratory distress syndrome (ARDS), which affects 200,000 patients yearly in the United States, accounting for more than $10 \%$ of total ICU admissions, with a hospital mortality risk of 30-40\% [105].

\section{Mechanisms of infection}

Influenza virus is transmitted primarily by infection of epithelial cells within the respiratory tract following inhalation. The virus then spreads to the upper and lower respiratory tracts causing the flu or viral pneumonia. The pathogenesis of both ANE and encephalopathy associated with influenza are poorly understood. Although some researchers suggested a direct role for brain infection in encephalopathy, viral particles are seldom recovered from CSF or brain samples [106]. Alternatively, encephalopathy patients frequently show high levels of serum and CSF cytokines, suggesting cytokine-mediated inflammation/cytokine storm as a potential cause [107-109].

\section{Clinical manifestation}

Influenza causes uncomplicated flu in a majority of cases. Although influenza viruses were not consistently shown to cause infective encephalitis in humans or animal models, they occasionally cause encephalopathy, usually presenting with normal CSF profile [110]. Rarely, influenza infections lead to severe encephalopathy with coma, extensive abnormalities on neuroimaging and high mortality rates, a syndrome called acute necrotizing encephalopathy, which affects largely children but also adults [111].

\section{Impacts on cognition}

Experimental studies show that the injection of Influenza A virus in mice's olfactory bulb caused cognitive impairment 14-20 weeks after the infection [112] as well as hippocampal morphology changes [113]. A case of severe amnesia with hippocampal imaging abnormality following Influenza A infection has been reported [114]. Other studies showed that Amyloid- $\beta$ protein has antimicrobial properties [115], specifically against Influenza A [116], which can explain its increased deposition in susceptible individuals (in special older adults) exposed to Influenza viruses. Additionally, influenza vaccination may decrease dementia risk in patients with chronic diseases $[117,118]$, underscoring a potential role of Influenza in human dementia.

Furthermore, cognitive impairment is very common in ARDS survivors. Seventy to $100 \%$ of ARDS patients are cognitively impaired on hospital discharge, $46-80 \%$ oneyear post-discharge, and $20 \%$ after five years $[119,120]$. Moreover, one-year post-discharge, ARDS survivors show high rates of anxiety, depression, executive dysfunction and post-traumatic stress disorder [121, 122]. Persistent cognitive impairment was reported after a 2-year follow-up: roughly half of patients displayed signs of cognitive impairment [123]. Putative biological mechanisms underlying long-term cognitive impairment in ARDS patients include hypoxia, cytokine-mediated damage, cerebral autoregulation disruption, and blood-brain barrier damage-associated decrease in Amyloid- $\beta$ clearance [124].

\section{Coronaviruses and COVID-19}

To our knowledge, no articles have investigated cognitive decline/impairment following the middle east respiratory syndrome (MERS) or the severe acute respiratory syndrome-coronavirus-1 (SARS-CoV-1). Although several studies have reported neuropsychiatric symptoms associated with the severe acute respiratory syndrome-coronavirus-2 (SARS-CoV-2) [13, 125], evidence of SARS-CoV-2 impact on human cognition remains scarce. Coronavirus disease 2019 (COVID-19) is caused by a RNA virus of the Coronaviridae family, and has been initially recognized as an agent of severe acute respiratory syndrome-related coronavirus (SARS-CoV) [126]. Although initially regarded as affecting the respiratory system with occasional gastrointestinal symptoms [127], subsequent reports showed that COVID-19 may also affect other major body organs, including renal, cardiovascular, and central nervous systems (CNS) [16, 125, 128].

COVID-19 has been recognized as a disease with pandemic consequences by World Health Organization in early March, 2020 [129]. Thenceforth, it has been infected almost 200 million people and killed more than 2.6 million people around 223 countries the world [130]. Especially in low- and middle-income countries, such as Brazil, due to the lack of vaccines, this number is still rising [130]. Furthermore, lack is known about the effect of the vaccine on new variants of SARS-CoV-2 [131].

Based on a review of the available literature, some authors predicted a high incidence of psychiatric morbidity following the COVID-19 pandemic, such as depression, anxiety and post-traumatic stress disorder [132]. Emotional symptoms can be related to COVID-19 through interaction with major life events and psycho-social stressors [133-135] or arise from disruption of brain function and damage to nervous tissues $[17,136]$. Recent reports highlighting the risk for neuropsychiatric impairments secondary to COVID19 showed that SARS-CoV-2 infection is associated with non-negligible incidence of neurological and psychiatric 
manifestations and provided evidence that neuropsychiatric and cognitive symptoms may arise as a direct CNS infection by the virus also $[17,136]$.

Most studies on cognitive changes following SARS$\mathrm{CoV}-2$ infection focused on acute changes, mainly acute encephalopathy [137-139]. The occurrence of persistent cognitive deficits resulting from COVID-19 infection remains uncertain. Preliminary studies of convalescent COVID-19 patients using comprehensive neuropsychological assessment showed cognitive impairment two to four weeks after infection. Attentional deficits were the most relevant changes [140,141]. A recent population-based study showed that $26 \%$ of all those with neuropsychiatric disorders due to COVID-19 had a dementia-like syndrome, with a median patient age of 71 years [136]. Another study showed that cognitive impairment (mainly attention and executive dysfunctions) has been reported in $28-56 \%$ of patients with mild or asymptomatic COVID-19, which was correlated with decreased cortical thickness in the right gyrus rectus, and in language associated areas [17]. A recent article showed changes in working memory, set-shifting, divided attention, and processing speed in a cohort of 57 patients recovering from moderate/severe patients with COVID-19, not being associated with intubation length, psychiatric and clinical diagnosis [142].

MRI studies have shown brain structural and microstructural changes in COVID-19 patients [143-146], such as acute necrotizing encephalopathy [145], cortical signal intensity abnormalities and unilateral FLAIR or diffusion hyper-intensities in medial the temporal lobe (MTL) [144, 146] and hippocampal abnormalities [143, 147]. A small case series of COVID-19 patients with acute encephalopathy suggested that the disease may be associated with a specific frontal hypo-metabolism pattern on FDG-PET [148] that differs from usual findings in delirium [149]. These abnormalities are associated with encephalitis and may at least partially explain cognitive impairment in COVID-19.

SARS-CoV-2 may cause neuropsychiatric symptoms by various indirect mechanisms, such as a hypercoagulable state, neuro-inflammation, immunological and epigenetic changes [132]. Several studies implied that blood-brain barrier disruption is associated with encephalopathy, favoring the neuro-inflammation theory $[150,151]$. A possible mechanism for this theory might be hyper-activation of P2X7 receptors and a consequent NLRP3 inflammasome stimulation, triggering the inflammatory cascade [152]. The finding of coronavirus RNA in brain tissue of deceased patients raised the possibility of a direct brain injury mechanism [153]. This observation was corroborated by the finding of the virus in neural and endothelial cells in frontal lobe tissues [154], and in the cerebral spinal fluid of infected individuals $[147,155,156]$. Additionally, SARS-CoV-2 was found in astrocytes of all deceased patients with brain damage, underscoring the fact that brain may be a sanctuary for SARS-CoV-2 [17]. A recent article found SARS$\mathrm{CoV}-2$ virus in $53 \%$ of brain tissues of people who died by COVID-19, even though brain lesions were non-specific and could not be attributed to SARS-CoV-2 lesions directly [157]. SARS-CoV-2 RNA, however, is rarely identified in CSF samples of COVID-19 patients [158], and most cases of COVID-associated neurological symptoms are CSF-RTPCR-negative, including encephalopathic patients [128, 137, 159]. CSF analysis of patients with neurological symptoms showed SARS-CoV-2 immunoreactivity, resulting from serum antibody leakage to the CSF, rather than to intrathecal antibody production $[150,160]$.

Knowledge acquired from other CoVs outbreaks (SARS$\mathrm{CoV}$ and MERS-CoV) has suggested potential neuro-invasive routes. The upper airways and the olfactory neuroepithelium, are the initial step for odor identification [161, 162]. Olfactory cells express angiotensin-converting enzyme isoform 2 (ACE-2) and type II serine protease (TMPRSS-2), which may represent the viral entry point to the CNS [163]. Several RNA viruses can undergo axonal transport to different brain structures causing acute encephalitis [164-166]. A recent study pointed out to the neural-mucosa interface in olfactory mucosa as a potential port of CNS entry for SARS-CoV-2 [167]. Finally, the cytokine storm theory proposes that SARS-CoV-2 inflammatory response in the CNS is mediated by the massive glial cell cytokine release, such as IL1b, IL-6, and IFN I-III [168, 169]. Low ACE-2 expression is noted in both neurons and glial cells [170].

Intranasal SARS-CoV-1 inoculation (80\% homology to SARS-CoV-2) in K18-hACE2 mutant mice (with the human form of ACE-2) resulted in the viral presence throughout the CNS, and was associated with local inflammatory mediators, respiratory dysfunction, and high mortality, with only mild lung infection [171, 172]. These findings suggest the importance of a CNS mechanism in virus-induced evolution and respiratory complications. CNS expression of ACE-2 expression in the CNS cells cannot isolatedly account for susceptibility to infection. Lungs and intestines usually show significant signs of viral infection and inflammation, which may be associated with high ACE-2 levels in pneumocytes and enterocytes. However, endothelial cells, which also express high ACE-2 levels do not display correspondingly high SARS-CoV infection levels [173].

In addition to the passage through the nasal neuro-epithelium route, independently from lower airway passage, evidence is accumulating suggesting that the virus initially infects peripheral nerve terminals and, through a transsynaptic mechanism, enters the CNS [174]. Trans-synaptic routes have been reported in different coronaviruses (CoVs), such as HEV67 [175, 176] and in the avian bronchitis virus $[177,178]$. Direct dorsal root ganglia infection in rats resulted in the presence of SARS-CoV in the CNS 
[176]. Electron microscopy data confirmed the presence of the virus in neuronal vesicles. CNS viral invasion can occur through vagus nerve mediated trans-synaptic route, through intranasal inoculation of the influenza virus [177]. Partially (ipsilaterally) vagotomized animals inoculated with the virus showed viral presence in the root ganglia, bilaterally. The virus reached the ganglion contralateral to the de-afferentation first, suggesting a less effective transport after vagus nerve injury. In SARS-CoV-2, trans-nasal and trans-synaptic mechanisms might allow the virus to invade the olfactory bulb and brainstem, with both being the possible initial site for CNS invasion [179]. Once the virus enters the CNS, it affects neurons, microglia, oligodendrocytes, and especially astrocytes, undermining neurons viability $[17,179,180]$.

Abate et al. [18] reviewed the different mechanisms by which SARS-CoV-2 infection might increase Alzheimer's disease (AD) risk, which could be extrapolated to other cognitive diseases. Direct viral neuro-invasion, as hypothesized above, and its association with ACE- 2 expression in brain, especially in glial cells, could lead to oxidative stress and neuronal loss, due to both microglia and astrocyte activation, and increased nitric oxide (NO) production. [181, 182]. The finding that SARS-CoV-2 infects astrocytes [17] and its role with amyloid- $\beta$ (A $\beta)$ deposition, underscores a possible link between COVID-19 infection and AD. A $\beta$ has also been shown to act as an antimicrobial peptide that may be overproduced in an immunologic mechanism [115]. Additionally, individuals with the ApoE3 allele may be more susceptible to severe forms of COVID-19 disease [183]. The connection between ApoE4 genotype, neuro-inflammation, and AD pathology should be further investigated [184]. Additionally, hypercoagulable states may induce micro-vascular disease and induce vascular dementia and AD [185]. Figure 1 summarizes the neurobiological impact of SARS-CoV-2 on cognition.

\section{Clinical implications}

It is important that health professionals be aware of the potential impact of COVID-19 in Central Nervous System, especially in cognition. It could impact not only older individuals with cognitive impairment, but also healthy individuals more susceptible to it. More studies should be done to identify these susceptible individuals, its relationship with disease severity, the pathophysiological mechanisms of this impairment, as well as to understand the long-term consequences of the cognitive deficits. Health managers should also promote campaigns and continuing education programs to help physicians and other health professionals to identify and deal with these emerging issues.

Moreover, the need of an approach to deal with these cognitive impairments is urgent. The spread of cognitive rehabilitation techniques is indispensable, as it has been showed to be effective and can be used through several different cognitive deficits and etiologies [186]. Also, the use of therapeutic agents to prevent and treat cognitive impairment following virus infections has been recently proposed. Wozniak and Itzhaki [187] in a narrative review, pose the provocative question whether it is time to initiate using antiviral agents for AD. Previous research has found that the development of anti-herpes medications had a positive impact, reducing the incidence of AD [56]. Current randomized controlled trials (RCTs) are investigating the effect of antiviral therapy for

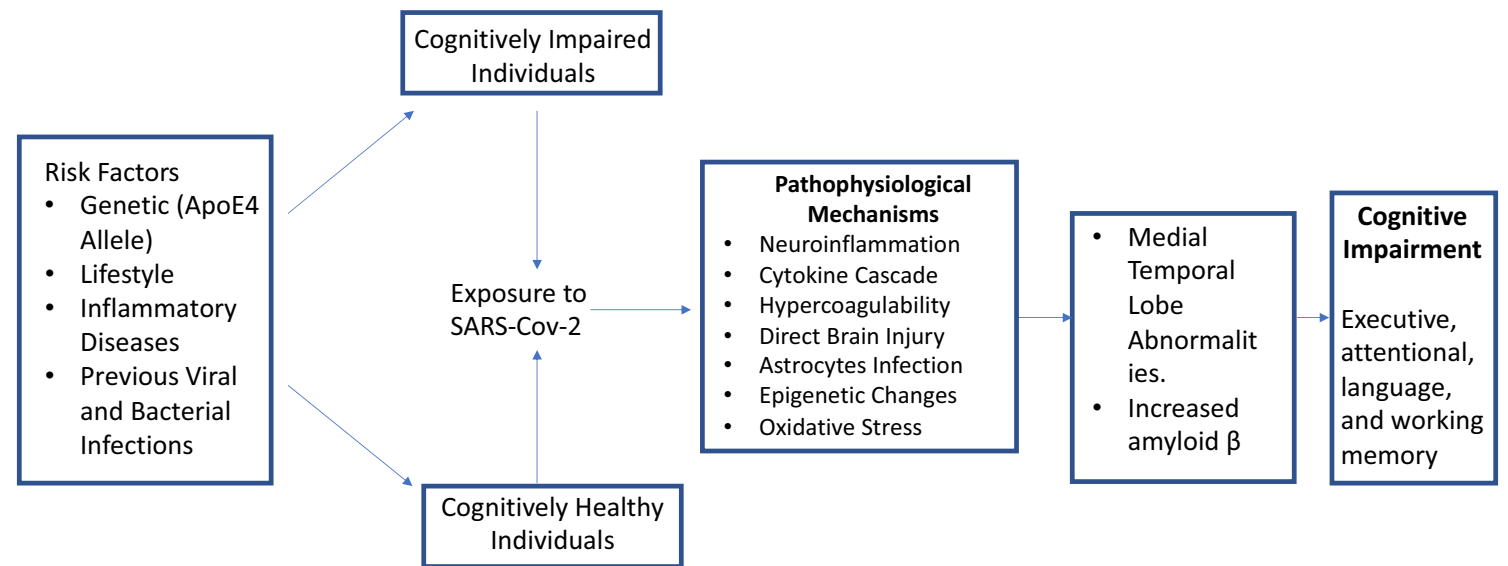

Fig. 1 Proposed pathophysiological mechanisms of the impact of SARS-CoV-2 infection on human cognition. First, risk factors, such as genetic, lifestyle, inflammatory diseases and previous viral and bacterial infections, might interact with exposure to SARS-CoV-2 in brains of both cognitively healthy and impaired individuals. It may induce several different mechanisms, such as neuro-inflammation, cytokine cascade, hypercoagulability, direct brain injury, astrocytes infection, epigenetic changes and oxidative stress, which together may induce medical-temporal lobe abnormalities and/or increased amyloid- $\beta$. These different pathways might induce a cognitive impairment, mainly in executive, attentional, language and working memory areas 
the treatment of AD [188]. Antibacterial therapy has also been suggested as an alternative for the treatment of senile dementia [10].

Some authors have suggested that due to anti-inflammatory properties, antimalarial drugs could be used to prevent neuropsychiatric COVID-19 complications [189]. Additionally, anticholinergic agent was proposed to reduce cytokine storm and $\mathrm{A} \beta$ deposition [190]. Furthermore, adamantane agents were suggested to play a potential neurocognitive protective effect in cognitively impaired patients [191]. So far, these agents were not proven to reduce mortality or morbidity due to SARS-CoV-2 infections.

\section{Limitations}

This paper has several limitations. First, due to the narrative nature of this review, there is a selection bias of articles. Second, we chose only six out of several different acute viral infections and virus-related syndromes. Our intent was to provide a wide scenario including both ubiquitous viruses causing disease worldwide (HSV-1, VZV, Influenzae), and viruses with marked regional relevance (WNV, JEV). Third, COVID-19 is an ongoing and dynamic epidemic. Many new articles are published daily, which makes reviewing this ever-changing field challenging. For instance, we made projections about post-COVID-19, because long-term studies on cognitive outcomes are largely lacking. We hope these projections will soon be confronted with original data from ongoing studies.

\section{Conclusion}

In sum, several viral agents have been shown to affect human cognition by distinct pathogenetic mechanisms. Some of these pathogens may cause long-term cognitive impairment, including parenchymal brain damage due to the direct CNS infection or to indirect mechanisms leading to disrupted brain function, such as hypercoagulable states and neuroinflammation. Recently, a wide body of evidence has shown that COVID-19 might lead to neuropsychiatric issues, especially cognitive impairments. However, lack is known about the pathophysiological mechanisms. Thus, it is crucial to understand the cognitive impact of acute viral infections and how it could be incorporate in the understanding of clinical impairments of COVID-19 in central nervous system. This knowledge may help us understand and predict possible long-term cognitive outcomes of COVID-19, helping both patients and health providers to cope better with this still unknown disease.

\section{Declarations}

Conflict of interest The authors declare no conflict of interest.

\section{References}

1. Ritchie K, Artero S, Touchon J (2001) Classification criteria for mild cognitive impairment: a population-based validation study. Neurology 56:37-42. https://doi.org/10.1212/wnl.56.1.37

2. Gauthier S, Reisberg B, Zaudig M, Petersen RC, Ritchie K, Broich K, Belleville S, Brodaty H, Bennett D, Chertkow H, Cummings JL, de Leon M, Feldman H, Ganguli M, Hampel H, Scheltens P, Tierney MC, Whitehouse P, Winblad B (2006) Mild cognitive impairment. Lancet 367:1262-1270. https://doi.org/10. 1016/s0140-6736(06)68542-5

3. Cunningham EL, McGuinness B, Herron B, Passmore AP (2015) Dementia. Ulster Med J 84:79-87

4. Nitrini R, Bottino CM, Albala C, Custodio Capuñay NS, Ketzoian C, Llibre Rodriguez JJ, Maestre GE, Ramos-Cerqueira AT, Caramelli P (2009) Prevalence of dementia in Latin America: a collaborative study of population-based cohorts. Int Psychogeriatr 21:622-630. https://doi.org/10.1017/s1041610209009430

5. Itzhaki RF, Wozniak MA (2007) Viral infection and cognitive decline. J Am Geriatr Soc 55:131-131. https://doi.org/10.1111/j. 1532-5415.2006.01001.x

6. Dobson CB, Wozniak MA, Itzhaki RF (2003) Do infectious agents play a role in dementia? Trends Microbiol 11:312-317. https://doi.org/10.1016/s0966-842x(03)00146-x

7. Harris SA, Harris EA (2015) Herpes simplex virus type 1 and other pathogens are key causative factors in sporadic Alzheimer's disease. J Alzheimers Dis 48:319-353. https://doi.org/10.3233/ jad-142853

8. Muñoz LS, Garcia MA, Gordon-Lipkin E, Parra B, Pardo CA (2018) Emerging viral infections and their impact on the global burden of neurological disease. Semin Neurol 38:163-175. https://doi.org/10.1055/s-0038-1647247

9. Monto AS (2005) The epidemiology of viral infections. In: Topley WWC, Wilson GST, Collier LH, Mahy BWJ, Meulen VT (eds) Topley \& Wilson's microbiology and microbial infections, 10th edn. Hodder Arnold, London

10. Panza F, Lozupone M, Solfrizzi V, Watling M, Imbimbo BP (2019) Time to test antibacterial therapy in Alzheimer's disease. Brain 142:2905-2929. https://doi.org/10.1093/brain/awz244

11. Hosseini S, Wilk E, Michaelsen-Preusse K, Gerhauser I, Baumgärtner W, Geffers R, Schughart K, Korte M (2018) Longterm neuroinflammation induced by influenza a virus infection and the impact on hippocampal neuron morphology and function. J Neurosci 38:3060-3080. https://doi.org/10.1523/jneurosci. 1740-17.2018

12. Aiello AE, Haan M, Blythe L, Moore K, Gonzalez JM, Jagust W (2006) The influence of latent viral infection on rate of cognitive decline over 4 years. J Am Geriatr Soc 54:1046-1054. https:// doi.org/10.1111/j.1532-5415.2006.00796.x

13. Aghagoli G, Gallo Marin B, Katchur NJ, Chaves-Sell F, Asaad WF, Murphy SA (2020) Neurological involvement in covid-19 and potential mechanisms: a review. Neurocrit Care. https://doi. org/10.1007/s12028-020-01049-4

14. Sochocka M, Zwolińska K, Leszek J (2017) The infectious etiology of Alzheimer's disease. Curr Neuropharmacol 15:996-1009. https://doi.org/10.2174/1570159x15666170313122937

15. Nimgaonkar VL, Yolken RH, Wang T, Chang CC, McClain L, McDade E, Snitz BE, Ganguli M (2016) Temporal cognitive decline associated with exposure to infectious agents in a 
population-based, aging cohort. Alzheimer Dis Assoc Disord 30:216-222. https://doi.org/10.1097/wad.0000000000000133

16. Chen T, Wu D, Chen H, Yan W, Yang D, Chen G, Ma K, Xu D, Yu H, Wang H, Wang T, Guo W, Chen J, Ding C, Zhang X, Huang J, Han M, Li S, Luo X, Zhao J, Ning Q (2020) Clinical characteristics of 113 deceased patients with coronavirus disease 2019: retrospective study. BMJ 368:m1091. https://doi.org/10. 1136/bmj.m1091

17. Crunfli F, Corasolla Carregari V, Veras FP, Vendramini PH, Valenca AGF, Antunes ASLM, Brandao-Teles C, Zuccoli GdS, Reis-de-Oliveira G, Silva-Costa LC, Saia-Cereda VM, Codo AC, Parise PL, Toledo-Teixeira DA, de Souza GF, Muraro SP, Melo BMS, Almeida GM, Firmino EMS, Ludwig RG, Palermo Ruiz G, Knittel TL, Davanzo GG, Gerhardt JA, Rodrigues PB, Forato J, Amorim MR, Brunetti Silva N, Martini MC, Benatti MN, Batah S, Siyuan L, Pereira Silva REM, João RB, Scardua Silva L, Nogueira MH, Karmann Aventurato I, Rabelo de Brito M, Machado Alvim MK, da Silva Junior JR, Damião LL, Castilho Stefano MEdP, Pereira de Sousa IM, Dias da Rocha E, Gonçalves SM, Lopes da Silva LH, Bettini V, Machado de Campos B, Ludwig G, Mendes Viana RM, Martins R, Vieira AS, Alves-Filho JC, de Arruda NE, Sebollela A, Cendes F, Cunha FQ, Damásio A, Vinolo MAR, Munhoz CD, Rehen SK, Mauad T, Duarte-Neto AN, Ferraz da Silva LF, Dolhnikoff M, Saldiva P, Todorovic Fabro A, Farias AS, Moraes-Vieira PMM, Proença Módena JL, Lin Yasuda C, Mori MA, Cunha TM, Martins-deSouza D (2020) Sars-cov-2 infects brain astrocytes of covid-19 patients and impairs neuronal viability. medRxiv. https://doi.org/ 10.1101/2020.10.09.20207464

18. Abate G, Memo M, Uberti D (2020) Impact of covid-19 on Alzheimer's disease risk: viewpoint for research action. Healthcare (Basel) 8:286. https://doi.org/10.3390/healthcare8030286

19. de Erausquin GA, Snyder H, Carrillo M, Hosseini AA, Brugha TS, Seshadri S (2021) The chronic neuropsychiatric sequelae of covid-19: the need for a prospective study of viral impact on brain functioning. Alzheimers Dement. https://doi.org/10.1002/ alz. 12255

20. Ferrari R (2015) Writing narrative style literature reviews. Med Writ 24:230-235. https://doi.org/10.1179/2047480615Z.00000 0000329

21. Green BN, Johnson CD, Adams A (2006) Writing narrative literature reviews for peer-reviewed journals: secrets of the trade. $\mathrm{J}$ Chiropr Med 5:101-117. https://doi.org/10.1016/s0899-3467(07) 60142-6

22. Borson S (2010) Cognition, aging, and disabilities: conceptual issues. Phys Med Rehabil Clin N Am 21:375-382. https://doi. org/10.1016/j.pmr.2010.01.001

23. Masters CL, Bateman R, Blennow K, Rowe CC, Sperling RA, Cummings JL (2015) Alzheimer's disease. Nat Rev Dis Prim 1:15056. https://doi.org/10.1038/nrdp.2015.56

24. Sittinger H, Müller M, Schweizer I, Merkelbach S (2002) Mild cognitive impairment after viral meningitis in adults. J Neurol 249:554-560. https://doi.org/10.1007/s004150200064

25. Venkatesan A, Tunkel AR, Bloch KC, Lauring AS, Sejvar J, Bitnun A, Stahl JP, Mailles A, Drebot M, Rupprecht CE, Yoder J, Cope JR, Wilson MR, Whitley RJ, Sullivan J, Granerod J, Jones C, Eastwood K, Ward KN, Durrheim DN, Solbrig MV, Guo-Dong L, Glaser CA (2013) Case definitions, diagnostic algorithms, and priorities in encephalitis: consensus statement of the international encephalitis consortium. Clin Infect Dis 57:1114-1128. https://doi.org/10.1093/cid/cit458

26. Tapiainen T, Prevots R, Izurieta HS, Abramson J, Bilynsky R, Bonhoeffer J, Bonnet MC, Center K, Galama J, Gillard P, Griot M, Hartmann K, Heininger U, Hudson M, Koller A, Khetsuriani N, Khuri-Bulos N, Marcy SM, Matulionyte R, Schöndorf I, Sejvar J, Steele R (2007) Aseptic meningitis: case definition and guidelines for collection, analysis and presentation of immunization safety data. Vaccine 25:5793-5802. https://doi.org/10. 1016/j.vaccine.2007.04.058

27. Mailles A, Stahl JP (2009) Infectious encephalitis in france in 2007: a national prospective study. Clin Infect Dis 49:18381847. https://doi.org/10.1086/648419

28. George BP, Schneider EB, Venkatesan A (2014) Encephalitis hospitalization rates and inpatient mortality in the United States, 2000-2010. PLoS ONE 9:e104169. https://doi.org/10.1371/journ al.pone. 0104169

29. Bodilsen J, Storgaard M, Larsen L, Wiese L, Helweg-Larsen J, Lebech AM, Brandt C, Østergaard C, Nielsen H (2018) Infectious meningitis and encephalitis in adults in Denmark: a prospective nationwide observational cohort study (dasgib). Clin Microbiol Infect 24:1102.e1-1102.e5. https://doi.org/10.1016/j. cmi.2018.01.016

30. Hjalmarsson A, Blomqvist P, Sköldenberg B (2007) Herpes simplex encephalitis in Sweden, 1990-2001: incidence, morbidity, and mortality. Clin Infect Dis 45:875-880. https://doi.org/10. 1086/521262

31. Modi S, Mahajan A, Dharaiya D, Varelas P, Mitsias P (2017) Burden of herpes simplex virus encephalitis in the United States. J Neurol 264:1204-1208. https://doi.org/10.1007/ s00415-017-8516-X

32. Bradshaw MJ, Venkatesan A (2016) Herpes simplex virus-1 encephalitis in adults: pathophysiology, diagnosis, and management. Neurotherapeutics 13:493-508. https://doi.org/10.1007/ s13311-016-0433-7

33. Mori I, Nishiyama Y, Yokochi T, Kimura Y (2005) Olfactory transmission of neurotropic viruses. J Neurovirol 11:129-137. https://doi.org/10.1080/13550280590922793

34. Dagsdóttir HM, Sigurðardóttir B, Gottfreðsson M, Kristjánsson M, Löve A, Baldvinsdóttir GE, Guðmundsson S (2014) Herpes simplex encephalitis in Iceland 1987-2011. Springerplus 3:524. https://doi.org/10.1186/2193-1801-3-524

35. Balin BJ, Hudson AP (2018) Herpes viruses and Alzheimer's disease: new evidence in the debate. Lancet Neurol 17:839-841. https://doi.org/10.1016/S1474-4422(18)30316-8

36. Duggan MR, Torkzaban B, Ahooyi TM, Khalili K (2020) Potential role for herpesviruses in Alzheimer's disease. J Alzheimers Dis 78:855-869. https://doi.org/10.3233/JAD-200814

37. Eimer WA, Vijaya Kumar DK, Navalpur Shanmugam NK, Rodriguez AS, Mitchell T, Washicosky KJ, György B, Breakefield XO, Tanzi RE, Moir RD (2018) Alzheimer's disease-associated $\beta$-amyloid is rapidly seeded by herpesviridae to protect against brain infection. Neuron 99:56-63.e53. https://doi.org/10.1016/j. neuron.2018.06.030

38. Hokkanen L, Launes J (2007) Neuropsychological sequelae of acute-onset sporadic viral encephalitis. Neuropsychol Rehabil 17:450-477. https://doi.org/10.1080/09602010601137039

39. Verfaellie M, Croce P, Milberg WP (1995) The role of episodic memory in semantic learning: an examination of vocabulary acquisition in a patient with amnesia due to encephalitis. Neurocase 1:291-304. https://doi.org/10.1080/13554799508402374

40. Verfaellie M, Koseff P, Alexander MP (2000) Acquisition of novel semantic information in amnesia: effects of lesion location. Neuropsychologia 38:484-492. https://doi.org/10.1016/ s0028-3932(99)00089-5

41. McCarthy RA, Kopelman MD, Warrington EK (2005) Remembering and forgetting of semantic knowledge in amnesia: a 16-year follow-up investigation of RFR. Neuropsychologia 43:356-372. https://doi.org/10.1016/j.neuropsychologia.2004. 06.024

42. Stefanacci L, Buffalo EA, Schmolck H, Squire LR (2000) Profound amnesia after damage to the medial temporal lobe: a neuroanatomical and neuropsychological profile of patient e. P. J 
Neurosci 20:7024-7036. https://doi.org/10.1523/jneurosci.2018-07024.2000

43. Levy DA, Bayley PJ, Squire LR (2004) The anatomy of semantic knowledge: medial vs. lateral temporal lobe. Proc Natl Acad Sci USA 101:6710-6715. https://doi.org/10.1073/pnas.0401679101

44. Wilson BA, Baddeley AD, Kapur N (1995) Dense amnesia in a professional musician following herpes simplex virus encephalitis. J Clin Exp Neuropsychol 17:668-681. https://doi.org/10. 1080/01688639508405157

45. Damasio AR, Tranel D (1990) Knowing that 'Colorado' goes with 'Denver' does not imply knowledge that 'Denver' is in 'Colorado.' Behav Brain Res 40:193-200. https://doi.org/10. 1016/0166-4328(90)90076-Q

46. Tranel D, Damasio AR (1993) The covert learning of affective valence does not require structures in hippocampal system or amygdala. J Cogn Neurosci 5:79-88. https://doi.org/10.1162/ jocn.1993.5.1.79

47. Kapur N, Barker S, Burrows EH, Ellison D, Brice J, Illis LS, Scholey K, Colbourn C, Wilson B, Loates M (1994) Herpes simplex encephalitis: long term magnetic resonance imaging and neuropsychological profile. J Neurol Neurosurg Psychiatry 57:1334-1342. https://doi.org/10.1136/jnnp.57.11.1334

48. Pietrini V, Nertempi P, Vaglia A, Revello MG, Pinna V, FerroMilone F (1988) Recovery from herpes simplex encephalitis: selective impairment of specific semantic categories with neuroradiological correlation. J Neurol Neurosurg Psychiatry 51:12841293. https://doi.org/10.1136/jnnp.51.10.1284

49. Utley TF, Ogden JA, Gibb A, McGrath N, Anderson NE (1997) The long-term neuropsychological outcome of herpes simplex encephalitis in a series of unselected survivors. Neuropsychiatry Neuropsychol Behav Neurol 10:180-189

50. Hokkanen L, Salonen O, Launes J (1996) Amnesia in acute herpetic and nonherpetic encephalitis. Arch Neurol 53:972-978. https://doi.org/10.1001/archneur.1996.00550100038013

51. Laurent B, Allegri RF, Thomas-Anterion C, Foyatier N, NaegeleFaure B, Pellat J (1991) Long term neuropsychological follow-up in patients with herpes simplex encephalitis and predominantly left-sided lesions. Behav Neurol 4:432895. https://doi.org/10. 3233/BEN-1991-4401

52. Mailles A, De Broucker T, Costanzo P, Martinez-Almoyna L, Vaillant V, Stahl JP (2012) Long-term outcome of patients presenting with acute infectious encephalitis of various causes in France. Clin Infect Dis 54:1455-1464. https://doi.org/10.1093/ $\mathrm{cid} / \mathrm{cis} 226$

53. Hokkanen L, Launes J (2000) Cognitive outcome in acute sporadic encephalitis. Neuropsychol Rev 10:151-167. https://doi. org/10.1023/a:1009079531196

54. Sköldenberg B, Forsgren M, Alestig K, Bergström T, Burman L, Dahlqvist E, Forkman A, Frydén A, Lövgren K, Norlin K et al (1984) Acyclovir versus vidarabine in herpes simplex encephalitis. Randomised multicentre study in consecutive swedish patients. Lancet (London, England) 2:707-711. https://doi.org/ 10.1016/s0140-6736(84)92623-0

55. Whitley RJ, Alford CA, Hirsch MS, Schooley RT, Luby JP, Aoki FY, Hanley D, Nahmias AJ, Soong SJ (1986) Vidarabine versus acyclovir therapy in herpes simplex encephalitis. N Engl J Med 314:144-149. https://doi.org/10.1056/nejm198601163140303

56. Tzeng NS, Chung CH, Lin FH, Chiang CP, Yeh CB, Huang SY, Lu RB, Chang HA, Kao YC, Yeh HW, Chiang WS, Chou YC, Tsao CH, Wu YF, Chien WC (2018) Anti-herpetic medications and reduced risk of dementia in patients with herpes simplex virus infections - a nationwide, population-based cohort study in Taiwan. Neurotherapeutics 15:417-429. https://doi.org/10.1007/ s13311-018-0611-x

57. Jaquet P, de Montmollin E, Dupuis C, Sazio C, Conrad M, Susset V, Demeret S, Tadie JM, Argaud L, Barbier F, Sarton
B, Chabane R, Daubin D, Brulé N, Lerolle N, Alves M, Da Silva D, Kalioubi AE, Silva S, Bailly P, Wolff M, Bouadma L, Timsit JF, Sonneville R (2019) Functional outcomes in adult patients with herpes simplex encephalitis admitted to the ICU: a multicenter cohort study. Intensive Care Med 45:1103-1111. https://doi.org/10.1007/s00134-019-05684-0

58. Granerod J, Ambrose HE, Davies NW, Clewley JP, Walsh AL, Morgan D, Cunningham R, Zuckerman M, Mutton KJ, Solomon T, Ward KN, Lunn MP, Irani SR, Vincent A, Brown DW, Crowcroft NS (2010) Causes of encephalitis and differences in their clinical presentations in England: a multicentre, population-based prospective study. Lancet Infect Dis 10:835-844. https://doi.org/10.1016/s1473-3099(10)70222-x

59. Richter ER, Dias JK, Gilbert JE 2nd, Atherton SS (2009) Distribution of herpes simplex virus type 1 and varicella zoster virus in ganglia of the human head and neck. J Infect Dis 200:1901-1906. https://doi.org/10.1086/648474

60. Nagel MA, Niemeyer CS, Bubak AN (2020) Central nervous system infections produced by varicella zoster virus. Curr Opin Infect Dis 33:273-278. https://doi.org/10.1097/qco.00000 00000000647

61. Steiner I, Kennedy PGE, Pachner AR (2007) The neurotropic herpes viruses: herpes simplex and varicella-zoster. Lancet Neurol 6:1015-1028. https://doi.org/10.1016/S1474-4422(07) 70267-3

62. Herlin LK, Hansen KS, Bodilsen J, Larsen L, Brandt C, Andersen C, Hansen BR, Rudolf Lüttichau H, Helweg-Larsen J, Wiese L, Storgaard M, Nielsen H, Mogensen TH (2020) Varicella zoster virus encephalitis in Denmark from 2015 to 2019-a nationwide prospective cohort study. Clin Infect Dis 72:1192-1199. https://doi.org/10.1093/cid/ciaa185

63. Kaewpoowat Q, Salazar L, Aguilera E, Wootton SH, Hasbun R (2016) Herpes simplex and varicella zoster cns infections: clinical presentations, treatments and outcomes. Infection 44:337-345. https://doi.org/10.1007/s15010-015-0867-6

64. Hansen MA, Samannodi MS, Castelblanco RL, Hasbun R (2020) Clinical epidemiology, risk factors, and outcomes of encephalitis in older adults. Clin Infect Dis 70:2377-2385. https://doi.org/10.1093/cid/ciz635

65. Grahn A, Hagberg L, Nilsson S, Blennow K, Zetterberg H, Studahl M (2013) Cerebrospinal fluid biomarkers in patients with Varicella-Zoster virus CNS infections. J Neurol 260:18131821. https://doi.org/10.1007/s00415-013-6883-5

66. Xiong W, Lu L, Xiao Y, Li J, Zhou D (2019) Mortality and disability due to Japanese encephalitis in elderly adults: evidence from an adult tertiary care center in West China. Front Neurol 10:918. https://doi.org/10.3389/fneur.2019.00918

67. Knope K, Doggett SL, Jansen CC, Johansen CA, Kurucz N, Feldman R, Lynch SE, Hobby MP, Sly A, Jardine A, Bennett S, Currie BJ, the National A, Malaria Advisory C (2019) Arboviral diseases and malaria in Australia, 2014-15: annual report of the national arbovirus and malaria advisory committee. Commun Dis Intell. https://doi.org/10.3332/cdi.2019.43. 14

68. Caldwell JP, Chen LH, Hamer DH (2018) Evolving epidemiology of Japanese encephalitis: implications for vaccination. Curr Infect Dis Rep 20:30. https://doi.org/10.1007/s11908-018-0635-8

69. Hsieh JT, St John AL (2020) Japanese encephalitis virus and its mechanisms of neuroinvasion. PLoS Pathog 16:e1008260. https://doi.org/10.1371/journal.ppat.1008260

70. Griffiths MJ, Turtle L, Solomon T (2014) Japanese encephalitis virus infection. Handb Clin Neurol 123:561-576. https://doi.org/ 10.1016/b978-0-444-53488-0.00026-2

71. Dung NM, Turtle L, Chong WK, Mai NT, Thao TT, Thuy TT, Kneen R, Phu NH, Wills B, Farrar J, Das K, Solomon T (2009) An evaluation of the usefulness of neuroimaging for the 
diagnosis of Japanese encephalitis. J Neurol 256:2052-2060. https://doi.org/10.1007/s00415-009-5249-5

72. Kumar R, Mathur A, Singh KB, Sitholey P, Prasad M, Shukla R, Agarwal SP, Arockiasamy J (1993) Clinical sequelae of japanese encephalitis in children. Indian J Med Res 97:9-13

73. Huy BV, Tu HC, Luan TV, Lindqvist R (1994) Early mental and neurological sequelae after Japanese b encephalitis. Southeast Asian J Trop Med Public Health 25:549-553

74. Yin Z, Wang X, Li L, Li H, Zhang X, Li J, Ning G, Li F, Liang X, Gao L, Liang X, Li Y (2015) Neurological sequelae of hospitalized Japanese encephalitis cases in Gansu province, China. Am J Trop Med Hyg 92:1125-1129. https://doi.org/10.4269/ ajtmh.14-0148

75. Simpson TW, Meiklejohn G (1947) Sequelae of Japanese b encephalitis1,2,3. Am J Trop Med Hyg 27:727-731. https:// doi.org/10.4269/ajtmh.1947.s1-27.727

76. Sarkari NB, Thacker AK, Barthwal SP, Mishra VK, Prapann S, Srivastava D, Sarkari M (2012) Japanese encephalitis (je) part II: 14 years' follow-up of survivors. J Neurol 259:58-69. https://doi.org/10.1007/s00415-011-6131-9

77. Chauhan PS, Khanna VK, Kalita J, Misra UK (2017) Japanese encephalitis virus infection results in transient dysfunction of memory learning and cholinesterase inhibition. Mol Neurobiol 54:4705-4715. https://doi.org/10.1007/s12035-016-9963-6

78. Petersen LR, Carson PJ, Biggerstaff BJ, Custer B, Borchardt SM, Busch MP (2013) Estimated cumulative incidence of West Nile virus infection in us adults, 1999-2010. Epidemiol Infect 141:591-595. https://doi.org/10.1017/s0950268812001070

79. Lohitharajah J, Malavige N, Arambepola C, Wanigasinghe J, Gamage R, Gunaratne P, Ratnayake P, Chang T (2017) Viral aetiologies of acute encephalitis in a hospital-based South Asian population. BMC Infect Dis 17:303. https://doi.org/10. 1186/s12879-017-2403-Z

80. Strausbaugh LJ, Marfin AA, Gubler DJ (2001) West Nile encephalitis: an emerging disease in the United States. Clin Infect Dis 33:1713-1719. https://doi.org/10.1086/322700

81. Camp JV, Nowotny N (2020) The knowns and unknowns of west nile virus in europe: What did we learn from the 2018 outbreak? Expert Rev Anti Infect Ther 18:145-154. https:// doi.org/10.1080/14787210.2020.1713751

82. Suen WW, Prow NA, Hall RA, Bielefeldt-Ohmann H (2014) Mechanism of West Nile virus neuroinvasion: a critical appraisal. Viruses 6:2796-2825. https://doi.org/10.3390/v6072 796

83. Sejvar JJ, Haddad MB, Tierney BC, Campbell GL, Marfin AA, Van Gerpen JA, Fleischauer A, Leis AA, Stokic DS, Petersen LR (2003) Neurologic manifestations and outcome of West Nile virus infection. JAMA 290:511-515. https://doi.org/10.1001/ jama.290.4.511

84. Bode AV, Sejvar JJ, Pape WJ, Campbell GL, Marfin AA (2006) West Nile virus disease: a descriptive study of 228 patients hospitalized in a 4-county region of Colorado in 2003. Clin Infect Dis 42:1234-1240. https://doi.org/10.1086/503038

85. Klee AL, Maidin B, Edwin B, Poshni I, Mostashari F, Fine A, Layton M, Nash D (2004) Long-term prognosis for clinical West Nile virus infection. Emerg Infect Dis 10:1405-1411. https://doi. org/10.3201/eid1008.030879

86. Patnaik JL, Harmon H, Vogt RL (2006) Follow-up of 2003 human West Nile virus infections, Denver, Colorado. Emerg Infect Dis 12:1129-1131. https://doi.org/10.3201/eid1207. 051399

87. Murray KO, Garcia MN, Rahbar MH, Martinez D, Khuwaja SA, Arafat RR, Rossmann S (2014) Survival analysis, longterm outcomes, and percentage of recovery up to 8 years postinfection among the houston West Nile virus cohort. PLoS ONE 9:e102953. https://doi.org/10.1371/journal.pone.0102953
88. Murray KO, Nolan MS, Ronca SE, Datta S, Govindarajan K, Narayana PA, Salazar L, Woods SP, Hasbun R (2018) The neurocognitive and mri outcomes of West Nile virus infection: preliminary analysis using an external control group. Front Neurol 9:111. https://doi.org/10.3389/fneur.2018.00111

89. Samaan Z, McDermid Vaz S, Bawor M, Potter TH, Eskandarian S, Loeb M (2016) Neuropsychological impact of West Nile virus infection: an extensive neuropsychiatric assessment of 49 cases in canada. PLoS ONE 11:e0158364. https://doi.org/10.1371/ journal.pone. 0158364

90. Popescu CP, Florescu SA, Hasbun R, Harxhi A, Evendar R, Kahraman H, Neuberger A, Codreanu D, Zaharia MF, Tosun S, Ceausu E, Ruta SM, Dragovac G, Pshenichnaya N, Gopatsa G, Shmaylenko O, Nagy É, Malbasa JD, Strbac M, Pandak N, Pullukcu H, Lakatos B, Cag Y, Cascio A, Coledan I, Oncu S, Erdem H (2020) Prediction of unfavorable outcomes in West Nile virus neuroinvasive infection-result of a multinational IdIri study. J Clin Virol 122:104213. https://doi.org/10.1016/j.jcv. 2019.104213

91. Carson PJ, Konewko P, Wold KS, Mariani P, Goli S, Bergloff P, Crosby RD (2006) Long-term clinical and neuropsychological outcomes of West Nile virus infection. Clin Infect Dis 43:723730. https://doi.org/10.1086/506939

92. McGill F, Griffiths MJ, Bonnett LJ, Geretti AM, Michael BD, Beeching NJ, McKee D, Scarlett P, Hart IJ, Mutton KJ, Jung A, Adan G, Gummery A, Sulaiman WAW, Ennis K, Martin AP, Haycox A, Miller A, Solomon T (2018) Incidence, aetiology, and sequelae of viral meningitis in UK adults: a multicentre prospective observational cohort study. Lancet Infect Dis 18:992-1003. https://doi.org/10.1016/s1473-3099(18)30245-7

93. Aldriweesh MA, Shafaay EA, Alwatban SM, Alkethami OM, Aljuraisi FN, Bosaeed M, Alharbi NK (2020) Viruses causing aseptic meningitis: a tertiary medical center experience with a multiplex PCR assay. Front Neurol 11:602267. https://doi.org/ 10.3389/fneur.2020.602267

94. Nesher L, Hadi CM, Salazar L, Wootton SH, Garey KW, Lasco T, Luce AM, Hasbun R (2016) Epidemiology of meningitis with a negative csf gram stain: under-utilization of available diagnostic tests. Epidemiol Infect 144:189-197. https://doi.org/10.1017/ S0950268815000850

95. da Rocha LC, Estofolete CF, de Aguiar Milhim BHG, Augusto MT, Zini N, da Silva GCD, Ferraz-Junior HC, Brienze VMS, Liso E, Cunha MS, Sabino EC, da Costa AC, Nogueira ML, Luchs A, Terzian ACB (2020) Enteric viruses circulating in undiagnosed central nervous system infections at tertiary hospital in são josé do rio preto, São Paulo, Brazil. J Med Virol 93:3539-3548. https://doi.org/10.1002/jmv.26216

96. Han SH, Choi HY, Kim JM, Park KR, Youn YC, Shin HW (2016) Etiology of aseptic meningitis and clinical characteristics in immune-competent adults. J Med Virol 88:175-179. https://doi. org/10.1002/jmv.24316

97. Chadwick DR (2005) Viral meningitis. Br Med Bull 75-76:1-14. https://doi.org/10.1093/bmb/ldh057

98. Jubelt B, Lipton HL (2014) Enterovirus/picornavirus infections. Handb Clin Neurol 123:379-416. https://doi.org/10.1016/b9780-444-53488-0.00018-3

99. Sinclair W, Omar M (2021) Enterovirus. In: StatPearls Publishing, Treasure Island. https://www.ncbi.nlm.nih.gov/books/ NBK562330/

100. Quist-Paulsen E, Ormaasen V, Kran A-MB, Dunlop O, Ueland PM, Ueland T, Eikeland R, Aukrust P, Nordenmark TH (2019) Encephalitis and aseptic meningitis: short-term and long-term outcome, quality of life and neuropsychological functioning. Sci Rep 9:16158. https://doi.org/10.1038/s41598-019-52570-2

101. Schmidt H, Heimann B, Djukic M, Mazurek C, Fels C, Wallesch CW, Nau R (2006) Neuropsychological sequelae of 
bacterial and viral meningitis. Brain 129:333-345. https://doi. org/10.1093/brain/awh711

102. Damsgaard J, Andersen H, Hjerrild S, Marinovskij E, Deutch S, Schembri A, Tarp B, Hagelskjaer Kristensen L, Age Lindberg J, Erlandsen M, Leutscher PD (2016) Neuropsychiatric symptoms among adult patients with aseptic meningitis: a prospective case series. Acta Psychiatr Scand 133:426-427. https://doi.org/10.1111/acps.12539

103. CDC (2019) Understanding influenza viruses. Centers for Disease Control and Prevention (CDC). https://www.cdc.gov/flu/ about/viruses/index.htm. Acessed 03 Feb 2021

104. Dawood FS, Iuliano AD, Reed C, Meltzer MI, Shay DK, Cheng P-Y, Bandaranayake D, Breiman RF, Brooks WA, Buchy P, Feikin DR, Fowler KB, Gordon A, Hien NT, Horby P, Huang QS, Katz MA, Krishnan A, Lal R, Montgomery JM, Mølbak K, Pebody R, Presanis AM, Razuri H, Steens A, Tinoco YO, Wallinga J, Yu H, Vong S, Bresee J, Widdowson M-A (2012) Estimated global mortality associated with the first 12 months of 2009 pandemic influenza a h1n1 virus circulation: a modelling study. Lancet Infect Dis 12:687-695. https://doi.org/10. 1016/S1473-3099(12)70121-4

105. Matthay MA, Zemans RL, Zimmerman GA, Arabi YM, Beitler JR, Mercat A, Herridge M, Randolph AG, Calfee CS (2019) Acute respiratory distress syndrome. Nat Rev Dis Primers 5:18. https://doi.org/10.1038/s41572-019-0069-0

106. Franková V, Jirásek A, Tůmová B (1977) Type a influenza: postmortem virus isolations from different organs in human lethal cases. Arch Virol 53:265-268. https://doi.org/10.1007/ bf01314671

107. Ichiyama $\mathrm{T}$, Isumi $\mathrm{H}$, Ozawa $\mathrm{H}$, Matsubara $\mathrm{T}$, Morishima $\mathrm{T}$, Furukawa S (2003) Cerebrospinal fluid and serum levels of cytokines and soluble tumor necrosis factor receptor in influenza virus-associated encephalopathy. Scand J Infect Dis 35:59-61. https://doi.org/10.1080/0036554021000026986

108. Fukumoto Y, Okumura A, Hayakawa F, Suzuki M, Kato T, Watanabe K, Morishima T (2007) Serum levels of cytokines and eeg findings in children with influenza associated with mild neurological complications. Brain Dev 29:425-430. https://doi.org/10.1016/j.braindev.2006.12.005

109. Okumura A, Abe S, Kidokoro H, Mizuguchi M (2009) Acute necrotizing encephalopathy: a comparison between influenza and non-influenza cases. Microbiol Immunol 53:277-280. https://doi.org/10.1111/j.1348-0421.2009.00124.x

110. Mastrolia MV, Rubino C, Resti M, Trapani S, Galli L (2019) Characteristics and outcome of influenza-associated encephalopathy/encephalitis among children in a tertiary pediatric hospital in italy, 2017-2019. BMC Infect Dis 19:1012. https://doi. org/10.1186/s12879-019-4636-5

111. Goenka A, Michael BD, Ledger E, Hart IJ, Absoud M, Chow G, Lilleker J, Lunn M, McKee D, Peake D, Pysden K, Roberts M, Carrol ED, Lim M, Avula S, Solomon T, Kneen R (2014) Neurological manifestations of influenza infection in children and adults: results of a national british surveillance study. Clin Infect Dis 58:775-784. https://doi.org/10.1093/cid/cit922

112. Beraki S, Aronsson F, Karlsson H, Ogren SO, Kristensson K (2005) Influenza a virus infection causes alterations in expression of synaptic regulatory genes combined with changes in cognitive and emotional behaviors in mice. Mol Psychiatry. https://doi.org/10.1038/sj.mp.4001545

113. Jurgens HA, Amancherla K, Johnson RW (2012) Influenza infection induces neuroinflammation, alters hippocampal neuron morphology, and impairs cognition in adult mice. J Neurosci 32:3958-3968. https://doi.org/10.1523/jneurosci.6389-11. 2012

114. Lopez J, Lomen-Hoerth C, Deutsch GK, Kerchner GA, Koshy A (2014) Influenza-associated global amnesia and hippocampal imaging abnormality. Neurocase 20:446-451. https://doi.org/10. 1080/13554794.2013.791864

115. Soscia SJ, Kirby JE, Washicosky KJ, Tucker SM, Ingelsson M, Hyman B, Burton MA, Goldstein LE, Duong S, Tanzi RE, Moir RD (2010) The Alzheimer's disease-associated amyloid betaprotein is an antimicrobial peptide. PLoS ONE 5:e9505. https:// doi.org/10.1371/journal.pone.0009505

116. White MR, Kandel R, Tripathi S, Condon D, Qi L, Taubenberger J, Hartshorn KL (2014) Alzheimer's associated $\beta$-amyloid protein inhibits influenza a virus and modulates viral interactions with phagocytes. PLoS ONE 9:e101364. https://doi.org/10.1371/ journal.pone.0101364

117. Liu JC, Hsu YP, Kao PF, Hao WR, Liu SH, Lin CF, Sung LC, Wu SY (2016) Influenza vaccination reduces dementia risk in chronic kidney disease patients: a population-based cohort study. Medicine (Baltimore) 95:e2868. https://doi.org/10.1097/md.00000 00000002868

118. Luo CS, Chi CC, Fang YA, Liu JC, Lee KY (2020) Influenza vaccination reduces dementia in patients with chronic obstructive pulmonary disease: a nationwide cohort study. J Investig Med 68:838-845. https://doi.org/10.1136/jim-2019-001155

119. Herridge MS, Moss M, Hough CL, Hopkins RO, Rice TW, Bienvenu OJ, Azoulay E (2016) Recovery and outcomes after the acute respiratory distress syndrome (ards) in patients and their family caregivers. Intensive Care Med 42:725-738. https:// doi.org/10.1007/s00134-016-4321-8

120. Wilcox ME, Brummel NE, Archer K, Ely EW, Jackson JC, Hopkins RO (2013) Cognitive dysfunction in icu patients: risk factors, predictors, and rehabilitation interventions. Crit Care Med 41:S81-98. https://doi.org/10.1097/CCM.0b013e3182a16946

121. Mikkelsen ME, Christie JD, Lanken PN, Biester RC, Thompson BT, Bellamy SL, Localio AR, Demissie E, Hopkins RO, Angus DC (2012) The adult respiratory distress syndrome cognitive outcomes study: Long-term neuropsychological function in survivors of acute lung injury. Am J Respir Crit Care Med 185:1307-1315. https://doi.org/10.1164/rccm.201111-2025OC

122. Kapfhammer HP, Rothenhäusler HB, Krauseneck T, Stoll C, Schelling G (2004) Posttraumatic stress disorder and healthrelated quality of life in long-term survivors of acute respiratory distress syndrome. Am J Psychiatry 161:45-52. https://doi.org/ 10.1176/appi.ajp.161.1.45

123. Hopkins RO, Weaver LK, Collingridge D, Parkinson RB, Chan KJ, Orme JF Jr (2005) Two-year cognitive, emotional, and quality-of-life outcomes in acute respiratory distress syndrome. Am J Respir Crit Care Med 171:340-347. https://doi.org/10.1164/ rccm.200406-763OC

124. Sasannejad C, Ely EW, Lahiri S (2019) Long-term cognitive impairment after acute respiratory distress syndrome: a review of clinical impact and pathophysiological mechanisms. Crit Care 23:352. https://doi.org/10.1186/s13054-019-2626-Z

125. Wu Y, Xu X, Chen Z, Duan J, Hashimoto K, Yang L, Liu C, Yang C (2020) Nervous system involvement after infection with covid-19 and other coronaviruses. Brain Behav Immun 87:18-22. https://doi.org/10.1016/j.bbi.2020.03.031

126. Gorbalenya AE, Baker SC, Baric RS, de Groot RJ, Drosten C, Gulyaeva AA, Haagmans BL, Lauber C, Leontovich AM, Neuman BW, Penzar D, Perlman S, Poon LLM, Samborskiy DV, Sidorov IA, Sola I, Ziebuhr J, Coronaviridae Study Group of the International Committee on Taxonomy of V (2020) The species severe acute respiratory syndrome-related coronavirus: Classifying 2019-ncov and naming it sars-cov-2. Nat Microbiol 5:536-544. https://doi.org/10.1038/s41564-020-0695-z

127. Ciotti M, Angeletti S, Minieri M, Giovannetti M, Benvenuto D, Pascarella S, Sagnelli C, Bianchi M, Bernardini S, Ciccozzi M (2019) Covid-19 outbreak: an overview. Chemotherapy 64:215223. https://doi.org/10.1159/000507423 
128. Helms J, Kremer S, Merdji H, Clere-Jehl R, Schenck M, Kummerlen C, Collange O, Boulay C, Fafi-Kremer S, Ohana M, Anheim M, Meziani F (2020) Neurologic features in severe sarscov-2 infection. N Engl J Med 382:2268-2270. https://doi.org/ 10.1056/NEJMc2008597

129. Mahase E (2020) Covid-19: Who declares pandemic because of "alarming levels" of spread, severity, and inaction. BMJ. https:// doi.org/10.1136/bmj.m1036

130. Medicine JHU (2021) Coronavirus resource center. Johns Hopkins University. https://www.coronavirus.jhu.edu. Acessed 03 Mar 2021

131. Mahase E (2021) Covid-19: Where are we on vaccines and variants? BMJ. https://doi.org/10.1136/bmj.n597

132. Troyer EA, Kohn JN, Hong S (2020) Are we facing a crashing wave of neuropsychiatric sequelae of covid-19? Neuropsychiatric symptoms and potential immunologic mechanisms. Brain Behav Immun 87:34-39. https://doi.org/10.1016/j.bbi.2020.04.027

133. Usher K, Bhullar N, Jackson D (2020) Life in the pandemic: social isolation and mental health. J Clin Nurs 29:2756-2757. https://doi.org/10.1111/jocn. 15290

134. Usher K, Durkin J, Bhullar N (2020) The covid-19 pandemic and mental health impacts. Int J Ment Health Nurs 29:315-318. https://doi.org/10.1111/inm.12726

135. Serafim AP, Gonçalves PD, Rocca CC, Lotufo Neto F (2020) The impact of covid-19 on Brazilian mental health through vicarious traumatization. Braz J Psychiatr 42:450. https://doi.org/10.1590/ 1516-4446-2020-0999

136. Varatharaj A, Thomas N, Ellul MA, Davies NWS, Pollak TA, Tenorio EL, Sultan M, Easton A, Breen G, Zandi M, Coles JP, Manji H, Al-Shahi Salman R, Menon DK, Nicholson TR, Benjamin LA, Carson A, Smith C, Turner MR, Solomon T, Kneen R, Pett SL, Galea I, Thomas RH, Michael BD, Allen C, Archibald N, Arkell J, Arthur-Farraj P, Baker M, Ball H, Bradley-Barker V, Brown Z, Bruno S, Carey L, Carswell C, Chakrabarti A, Choulerton J, Daher M, Davies R, Di Marco BR, Dima S, Dunley R, Dutta D, Ellis R, Everitt A, Fady J, Fearon P, Fisniku L, Gbinigie I, Gemski A, Gillies E, Gkrania-Klotsas E, Grigg J, Hamdalla H, Hubbett J, Hunter N, Huys A-C, Ihmoda I, Ispoglou S, Jha A, Joussi R, Kalladka D, Khalifeh H, Kooij S, Kumar G, Kyaw S, Li L, Littleton E, Macleod M, Macleod MJ, Madigan B, Mahadasa V, Manoharan M, Marigold R, Marks I, Matthews P, McCormick M, McInnes C, Metastasio A, Milburn-McNulty P, Mitchell C, Mitchell D, Morgans C, Morris H, Morrow J, Mubarak Mohamed A, Mulvenna P, Murphy L, Namushi R, Newman E, Phillips W, Pinto A, Price DA, Proschel H, Quinn T, Ramsey D, Roffe C, Ross Russell A, Samarasekera N, Sawcer S, Sayed W, Sekaran L, Serra-Mestres J, Snowdon V, Strike G, Sun J, Tang C, Vrana M, Wade R, Wharton C, Wiblin L, Boubriak I, Herman K, Plant G (2020) Neurological and neuropsychiatric complications of covid-19 in 153 patients: a UK-wide surveillance study. Lancet Psychiatry 7:875-882. https://doi.org/10.1016/S2215-0366(20) 30287-X

137. Tuma R, Guedes B, Carra R, Iepsen B, Rodrigues J, Camelo Filho AE, Kubota G, Ferrari M, Studart-Neto A, Oku M, Terrim S, Lopes C, Passos Neto CE, Dalben M, De Souza J, Baima JP, Da Silva T, Perissinotti I, Martin MdG, Goncalves M, Fortini I, Smid J, Adoni T, Lucatto L, Nitrini R, Gomes H, Castro LH (2020) Clinical, cerebrospinal fluid and neuroimaging findings in covid-19 encephalopathy: a case series. medRxiv. https://doi. org/10.1101/2020.08.28.20181883

138. Garg RK, Paliwal VK, Gupta A (2021) Encephalopathy in patients with covid-19: a review. J Med Virol 93:206-222. https://doi.org/10.1002/jmv.26207

139. Kihira S, Delman BN, Belani P, Stein L, Aggarwal A, Rigney B, Schefflein J, Doshi AH, Pawha PS (2020) Imaging features of acute encephalopathy in patients with covid-19: a case series.
Am J Neuroradiol 41:1804-1808. https://doi.org/10.3174/ajnr. A6715

140. Zhou H, Lu S, Chen J, Wei N, Wang D, Lyu H, Shi C, Hu S (2020) The landscape of cognitive function in recovered covid-19 patients. J Psychiatr Res 129:98-102. https://doi.org/10.1016/j. jpsychires.2020.06.022

141. Negrini F, Ferrario I, Mazziotti D, Berchicci M, Bonazzi M, de Sire A, Negrini S, Zapparoli L (2020) Neuropsychological features of severe hospitalized covid-19 patients at clinical stability and clues for post-acute rehabilitation. Arch Phys Med Rehabil 102:155-158. https://doi.org/10.1016/j.apmr.2020.09.376

142. Jaywant A, Vanderlind WM, Alexopoulos GS, Fridman CB, Perlis RH, Gunning FM (2021) Frequency and profile of objective cognitive deficits in hospitalized patients recovering from covid-19. Neuropsychopharmacology. https://doi.org/10.1038/ s41386-021-00978-8

143. Lu Y, Li X, Geng D, Mei N, Wu P-Y, Huang C-C, Jia T, Zhao Y, Wang D, Xiao A, Yin B (2020) Cerebral micro-structural changes in covid-19 patients - an MRI-based 3-month follow-up study. EClinicalMedicine 25:100484. https://doi.org/10.1016/j. eclinm.2020.100484

144. Kremer PS, Lersy F, Sèze PJd, Ferré PJ-C, Maamar A, CarsinNicol B, Collange PO, Bonneville PF, Adam G, Martin-Blondel PG, Rafiq M, Geeraerts PT, Delamarre L, Grand S, Krainik PA, Caillard PS, Constans PJM, Metanbou S, Heintz A, Helms PJ, Schenck M, Lefèbvre N, Boutet PC, Fabre X, Forestier G, Beaurepaire Id, Bornet G, Lacalm A, Oesterlé H, Bolognini F, Messie J, Hmeydia G, Benzakoun J, Oppenheim PC, Bapst B, Megdiche I, Henri-Feugeas M-C, Khalil PA, Gaudemer A, Jager L, Nesser P, Mba YT, Hemmert C, Feuerstein P, Sebag N, Carré S, Alleg M, Lecocq C, Schmitt E, Anxionnat PR, Zhu F, Comby P-O, Ricolfi PF, Thouant P, Desal PH, Boulouis G, Berge J, Kazémi A, Pyatigorskaya N, Lecler A, Saleme S, Edjlali-Goujon M, Kerleroux B, Zorn P-E, Mathieu M, Baloglu S, Ardellier F-D, Willaume T, Brisset JC, Boulay C, Mutschler V, Hansmann PY, Mertes PP-M, Schneider PF, Fafi-Kremer PS, Ohana PM, Meziani PF, David PJ-S, Meyer PN, Anheim PM (2020) Cotton PF Brain MRI findings in severe covid-19: a retrospective observational study. Radiology 297:242-251. https://doi.org/10.1148/ radiol.2020202222

145. Poyiadji N, Shahin G, Noujaim D, Stone M, Patel S, Griffith B (2020) Covid-19-associated acute hemorrhagic necrotizing encephalopathy: imaging features. Radiology 296:E119-E120. https://doi.org/10.1148/radiol.2020201187

146. Kandemirli SG, Dogan L, Sarikaya ZT, Kara S, Akinci C, Kaya D, Kaya Y, Yildirim D, Tuzuner F, Yildirim MS, Ozluk E, Gucyetmez B, Karaarslan E, Koyluoglu I, Kaya HSD, Mammadov O, Ozdemir IK, Afsar N, Yalcinkaya BC, Rasimoglu S, Guduk DE, Jima AK, Ilksoz A, Ersoz V, Eren MY, Celtik N, Arslan S, Korkmazer B, Dincer SS, Gulek E, Dikmen I, Yazici M, Unsal S, Ljama T, Demirel I, Ayyildiz A, Kesimci I, Deveci SB, Tutuncu M, Kizilkilic O, Telci L, Zengin R, Dincer A, Akinci IO, Kocer N (2020) Brain mri findings in patients in the intensive care unit with covid-19 infection. Radiology 297:E232-E235. https://doi. org/10.1148/radiol.2020201697

147. Moriguchi T, Harii N, Goto J, Harada D, Sugawara H, Takamino J, Ueno M, Sakata H, Kondo K, Myose N, Nakao A, Takeda M, Haro H, Inoue O, Suzuki-Inoue K, Kubokawa K, Ogihara S, Sasaki T, Kinouchi H, Kojin H, Ito M, Onishi H, Shimizu T, Sasaki Y, Enomoto N, Ishihara H, Furuya S, Yamamoto T, Shimada S (2020) A first case of meningitis/encephalitis associated with sars-coronavirus-2. Int J Infect Dis 94:55-58. https://doi. org/10.1016/j.ijid.2020.03.062

148. Delorme C, Paccoud O, Kas A, Hesters A, Bombois S, Shambrook P, Boullet A, Doukhi D, Le Guennec L, Godefroy N, Maatoug R, Fossati P, Millet B, Navarro V, Bruneteau G, 
Demeret S, Pourcher V (2020) Covid-19-related encephalopathy: a case series with brain fdg-pet/ct findings. Eur J Neurol 27:1651-2657. https://doi.org/10.1111/ene.14478

149. Haggstrom LR, Nelson JA, Wegner EA, Caplan GA (2017) 2-(18)f-fluoro-2-deoxyglucose positron emission tomography in delirium. J Cereb Blood Flow Metab 37:3556-3567. https:// doi.org/10.1177/0271678x17701764

150. Alexopoulos H, Magira E, Bitzogli K, Kafasi N, Vlachoyiannopoulos P, Tzioufas A, Kotanidou A, Dalakas MC (2020) Antisars-cov-2 antibodies in the csf, blood-brain barrier dysfunction, and neurological outcome: studies in 8 stuporous and comatose patients. Neurol Neuroimmunol Neuroinflamm 7:893. https://doi. org/10.1212/nxi.0000000000000893

151. Alquisiras-Burgos I, Peralta-Arrieta I, Alonso-Palomares LA, Zacapala-Gómez AE, Salmerón-Bárcenas EG, Aguilera P (2020) Neurological complications associated with the blood-brain barrier damage induced by the inflammatory response during sarscov-2 infection. Mol Neurobiol 58:520-535. https://doi.org/10. 1007/s12035-020-02134-7

152. Ribeiro DE, Oliveira-Giacomelli Á, Glaser T, Arnaud-Sampaio VF, Andrejew R, Dieckmann L, Baranova J, Lameu C, Ratajczak MZ, Ulrich H (2020) Hyperactivation of p2x7 receptors as a culprit of covid-19 neuropathology. Mol Psychiatry 26:1044-1059. https://doi.org/10.1038/s41380-020-00965-3

153. Puelles VG, Lütgehetmann M, Lindenmeyer MT, Sperhake JP, Wong MN, Allweiss L, Chilla S, Heinemann A, Wanner N, Liu S, Braun F, Lu S, Pfefferle S, Schröder AS, Edler C, Gross O, Glatzel M, Wichmann D, Wiech T, Kluge S, Pueschel K, Aepfelbacher M, Huber TB (2020) Multiorgan and renal tropism of sars-cov-2. N Eng1 J Med 383:590-592. https://doi.org/10.1056/ NEJMc2011400

154. Paniz-Mondolfi A, Bryce C, Grimes Z, Gordon RE, Reidy J, Lednicky J, Sordillo EM, Fowkes M (2020) Central nervous system involvement by severe acute respiratory syndrome coronavirus-2 (sars-cov-2). J Med Virol 92:699-702. https://doi.org/10.1002/ jmv. 25915

155. Huang YH, Jiang D, Huang JT (2020) Sars-cov-2 detected in cerebrospinal fluid by pcr in a case of covid-19 encephalitis. Brain Behav Immun 87:149. https://doi.org/10.1016/j.bbi.2020. 05.012

156. Khodamoradi Z, Hosseini SA, Gholampoor Saadi MH, Mehrabi Z, Sasani MR, Yaghoubi S (2020) Covid-19 meningitis without pulmonary involvement with positive cerebrospinal fluid pcr. Eur J Neurol 27:2668-2669. https://doi.org/10.1111/ene.14536

157. Matschke J, Lütgehetmann M, Hagel C, Sperhake JP, Schröder AS, Edler C, Mushumba H, Fitzek A, Allweiss L, Dandri M, Dottermusch M, Heinemann A, Pfefferle S, Schwabenland M, Sumner Magruder D, Bonn S, Prinz M, Gerloff C, Püschel K, Krasemann S, Aepfelbacher M, Glatzel M (2020) Neuropathology of patients with covid-19 in germany: a post-mortem case series. Lancet Neurol 19:919-929. https://doi.org/10.1016/ S1474-4422(20)30308-2

158. Destras G, Bal A, Escuret V, Morfin F, Lina B, Josset L (2020) Systematic sars-cov-2 screening in cerebrospinal fluid during the covid-19 pandemic. Lancet Microbe 1:e149. https://doi.org/10. 1016/s2666-5247(20)30066-5

159. Neumann B, Schmidbauer ML, Dimitriadis K, Otto S, Knier B, Niesen WD, Hosp JA, Günther A, Lindemann S, Nagy G, Steinberg T, Linker RA, Hemmer B, Bösel J (2020) Cerebrospinal fluid findings in covid-19 patients with neurological symptoms. J Neurol Sci 418:117090. https://doi.org/10.1016/j.jns.2020. 117090

160. Andriuta D, Roger PA, Thibault W, Toublanc B, Sauzay C, Castelain S, Godefroy O, Brochot E (2020) Covid-19 encephalopathy: detection of antibodies against sars-cov-2 in csf. J Neurol 267:2810-2811. https://doi.org/10.1007/s00415-020-09975-1
161. Smith TD, Bhatnagar KP (2019) Anatomy of the olfactory system. Handb Clin Neurol 164:17-28. https://doi.org/10.1016/ b978-0-444-63855-7.00002-2

162. Giacomelli A, Pezzati L, Conti F, Bernacchia D, Siano M, Oreni L, Rusconi S, Gervasoni C, Ridolfo AL, Rizzardini G, Antinori S, Galli M (2020) Self-reported olfactory and taste disorders in patients with severe acute respiratory coronavirus 2 infection: a cross-sectional study. Clin Infect Dis 71:889-890. https://doi.org/ $10.1093 / \mathrm{cid} / \mathrm{ciaa} 330$

163. Hoffmann M, Kleine-Weber H, Schroeder S, Krüger N, Herrler T, Erichsen S, Schiergens TS, Herrler G, Wu N-H, Nitsche A, Müller MA, Drosten C, Pöhlmann S (2020) Sars-cov-2 cell entry depends on ace 2 and tmprss 2 and is blocked by a clinically proven protease inhibitor. Cell 181:271-280.e278. https://doi.org/ 10.1016/j.cell.2020.02.052

164. Ehrengruber MU, Ehler E, Billeter MA, Naim HY (2002) Measles virus spreads in rat hippocampal neurons by cell-to-cell contact and in a polarized fashion. J Virol 76:5720-5728. https://doi. org/10.1128/jvi.76.11.5720-5728.2002

165. Calisher CH, Dodet B, Griffin D (2003) Emergence and control of zoonotic viral encephalitis. Emerg Infect Dis 9:1029-1030. https://doi.org/10.3201/eid0908.030319

166. Dubé M, Le Coupanec A, Wong AHM, Rini JM, Desforges M, Talbot PJ (2018) Axonal transport enables neuron-to-neuron propagation of human coronavirus oc43. J Virol 92:e00404-e418. https://doi.org/10.1128/jvi.00404-18

167. Meinhardt J, Radke J, Dittmayer C, Franz J, Thomas C, Mothes R, Laue M, Schneider J, Brünink S, Greuel S, Lehmann M, Hassan O, Aschman T, Schumann E, Chua RL, Conrad C, Eils R, Stenzel W, Windgassen M, Rößler L, Goebel H-H, Gelderblom HR, Martin H, Nitsche A, Schulz-Schaeffer WJ, Hakroush S, Winkler MS, Tampe B, Scheibe F, Körtvélyessy P, Reinhold D, Siegmund B, Kühl AA, Elezkurtaj S, Horst D, Oesterhelweg L, Tsokos M, Ingold-Heppner B, Stadelmann C, Drosten C, Corman VM, Radbruch H, Heppner FL (2021) Olfactory transmucosal sars-cov-2 invasion as a port of central nervous system entry in individuals with covid-19. Nat Neurosci 24:168-175. https://doi. org/10.1038/s41593-020-00758-5

168. Detje CN, Lienenklaus S, Chhatbar C, Spanier J, Prajeeth CK, Soldner C, Tovey MG, Schlüter D, Weiss S, Stangel M, Kalinke U (2015) Upon intranasal vesicular stomatitis virus infection, astrocytes in the olfactory bulb are important interferon beta producers that protect from lethal encephalitis. J Virol 89:27312738. https://doi.org/10.1128/jvi.02044-14

169. Steardo L, Steardo L Jr, Zorec R, Verkhratsky A (2020) Neuroinfection may contribute to pathophysiology and clinical manifestations of covid-19. Acta Physiol (Oxf) 229:e13473. https:// doi.org/10.1111/apha.13473

170. Yan T, Xiao R, Lin G (2020) Angiotensin-converting enzyme 2 in severe acute respiratory syndrome coronavirus and sars-cov-2: a double-edged sword? Faseb j 34:6017-6026. https://doi.org/10. 1096/fj.202000782

171. McCray PB, Pewe L, Wohlford-Lenane C, Hickey M, Manzel L, Shi L, Netland J, Jia HP, Halabi C, Sigmund CD, Meyerholz DK, Kirby P, Look DC, Perlman S (2007) Lethal infection of k18hACE2 mice infected with severe acute respiratory syndrome coronavirus. J Virol 81:813-821. https://doi.org/10.1128/jvi. 02012-06

172. Netland J, Meyerholz DK, Moore S, Cassell M, Perlman S (2008) Severe acute respiratory syndrome coronavirus infection causes neuronal death in the absence of encephalitis in mice transgenic for human ace2. J Virol 82:7264-7275. https://doi.org/10.1128/ jvi.00737-08

173. To KF, Lo AW (2004) Exploring the pathogenesis of severe acute respiratory syndrome (sars): the tissue distribution of the coronavirus (sars-cov) and its putative receptor, angiotensin-converting 
enzyme 2 (ace2). J Pathol 203:740-743. https://doi.org/10.1002/ path. 1597

174. Natoli S, Oliveira V, Calabresi P, Maia LF, Pisani A (2020) Does sars-cov-2 invade the brain? Translational lessons from animal models. Eur J Neurol 27:1764-1773. https://doi.org/10.1111/ene. 14277

175. Wang D, Hu B, Hu C, Zhu F, Liu X, Zhang J, Wang B, Xiang H, Cheng Z, Xiong Y, Zhao Y, Li Y, Wang X, Peng Z (2020) Clinical characteristics of 138 hospitalized patients with 2019 novel coronavirus-infected pneumonia in Wuhan, China. JAMA 323:1061-1069. https://doi.org/10.1001/jama.2020.1585

176. Li YC, Bai WZ, Hirano N, Hayashida T, Hashikawa T (2012) Coronavirus infection of rat dorsal root ganglia: ultrastructural characterization of viral replication, transfer, and the early response of satellite cells. Virus Res 163:628-635. https://doi. org/10.1016/j.virusres.2011.12.021

177. Matsuda K, Park CH, Sunden Y, Kimura T, Ochiai K, Kida H, Umemura $\mathrm{T}$ (2004) The vagus nerve is one route of transneural invasion for intranasally inoculated influenza a virus in mice. Vet Pathol 41:101-107. https://doi.org/10.1354/vp.41-2-101

178. Chasey D, Alexander DJ (1976) Morphogenesis of avian infectious bronchitis virus in primary chick kidney cells. Arch Virol 52:101-111. https://doi.org/10.1007/bf01317869

179. Tremblay M-E, Madore C, Bordeleau M, Tian L, Verkhratsky A (2020) Neuropathobiology of covid-19: the role for glia. Front Cell Neurosci 14:592214. https://doi.org/10.3389/fncel.2020. 592214

180. Song E, Zhang C, Israelow B, Lu-Culligan A, Prado AV, Skriabine S, Lu P, Weizman OE, Liu F, Dai Y, Szigeti-Buck K, Yasumoto Y, Wang G, Castaldi C, Heltke J, Ng E, Wheeler J, Alfajaro MM, Levavasseur E, Fontes B, Ravindra NG, Van Dijk D, Mane S, Gunel M, Ring A, Kazmi SAJ, Zhang K, Wilen CB, Horvath TL, Plu I, Haik S, Thomas JL, Louvi A, Farhadian SF, Huttner A, Seilhean D, Renier N, Bilguvar K, Iwasaki A (2020) Neuroinvasion of sars-cov-2 in human and mouse brain. bioRxiv. https:// doi.org/10.1101/2020.06.25.169946

181. Asiimwe N, Yeo SG, Kim MS, Jung J, Jeong NY (2016) Nitric oxide: exploring the contextual link with Alzheimer's disease. Oxid Med Cell Longev. https://doi.org/10.1155/2016/7205747

182. Li Y, Fu L, Gonzales DM, Lavi E (2004) Coronavirus neurovirulence correlates with the ability of the virus to induce proinflammatory cytokine signals from astrocytes and microglia. J Virol 78:3398-3406. https://doi.org/10.1128/jvi.78.7.3398-3406.2004
183. Kuo CL, Pilling LC, Atkins JL, Masoli JAH, Delgado J, Kuchel GA, Melzer D (2020) APOE e4 genotype predicts severe covid19 in the uk biobank community cohort. J Gerontol A Biol Sci Med Sci 75:2231-2232. https://doi.org/10.1093/gerona/glaa131

184. Tzioras M, Davies C, Newman A, Jackson R, Spires-Jones T (2019) Invited review: APOE at the interface of inflammation, neurodegeneration and pathological protein spread in Alzheimer's disease. Neuropathol Appl Neurobiol 45:327-346. https:// doi.org/10.1111/nan.12529

185. Gupta A, Watkins A, Thomas P, Majer R, Habubi N, Morris G, Pansari K (2005) Coagulation and inflammatory markers in Alzheimer's and vascular dementia. Int J Clin Pract 59:52-57. https://doi.org/10.1111/j.1742-1241.2004.00143.x

186. Cicerone KD, Dahlberg C, Malec JF, Langenbahn DM, Felicetti T, Kneipp S, Ellmo W, Kalmar K, Giacino JT, Harley JP, Laatsch L, Morse PA, Catanese J (2005) Evidence-based cognitive rehabilitation: updated review of the literature from 1998 through 2002. Arch Phys Med Rehabil 86:1681-1692. https://doi.org/ 10.1016/j.apmr.2005.03.024

187. Wozniak MA, Itzhaki RF (2010) Antiviral agents in Alzheimer's disease: hope for the future? Ther Adv Neurol Disord 3:141-152. https://doi.org/10.1177/1756285610370069

188. Devanand DP, Andrews H, Kreisl WC, Razlighi Q, Gershon A, Stern Y, Mintz A, Wisniewski T, Acosta E, Pollina J, Katsikoumbas M, Bell KL, Pelton GH, Deliyannides D, Prasad KM, Huey ED (2020) Antiviral therapy: Valacyclovir treatment of Alzheimer's disease (valad) trial: Protocol for a randomised, double-blind, placebo-controlled, treatment trial. BMJ Open 10:e032112. https://doi.org/10.1136/bmjopen-2019-032112

189. Ong WY, Go ML, Wang DY, Cheah IK, Halliwell B (2020) Effects of antimalarial drugs on neuroinflammation-potential use for treatment of covid-19-related neurologic complications. Mol Neurobiol 58:106-117. https://doi.org/10.1007/ s12035-020-02093-Z

190. Naughton SX, Raval U, Pasinetti GM (2020) Potential novel role of covid-19 in Alzheimer's disease and preventative mitigation strategies. J Alzheimers Dis 76:21-25. https://doi.org/10.3233/ jad-200537

191. Rejdak K, Grieb P (2020) Adamantanes might be protective from covid-19 in patients with neurological diseases: multiple sclerosis, parkinsonism and cognitive impairment. Mult Scler Relat Disord 42:102163. https://doi.org/10.1016/j.msard.2020.102163 